\title{
Review of the West Indian Arachnocoris Scott, 1881 (Hemiptera: Nabidae), with Descriptions of Two New Species, and a Catalog of the Species ${ }^{1}$
}

\author{
Javier E. Mercado², Jorge A. Santiago-Blay ${ }^{3}$, and Michael D. Webb ${ }^{4}$
}

\begin{abstract}
We review the West Indian species of Arachnocoris, a genus of spider-web dwelling kleptoparasitic nabids. We recognize five species: A. berytoides Uhler from Grenada, A. darlingtoni n. sp. from Hispaniola, A. karukerae Lopez-Moncet from Guadeloupe, A. portoricensis n. sp. from Puerto Rico, and A. trinitatis Bergroth from Trinidad. West Indian Arachnocoris antennal and profemoral color banding patterns are useful diagnostic characters and may have evolved to mimic their spider hosts, which are often island endemic spiders in the family Pholcidae. We provide a simplified and illustrated key to the species based on external characters. A catalog for the 16 recognized species of Arachnocoris is presented.
\end{abstract}

Keywords: Hemiptera, Nabidae, Arachnocoris, new species, Neotropical, West Indies

\section{Introduction}

The Nabidae are a relatively small family in the insect order Hemiptera with approximately 20-30 genera and 400-500 described species (Henry 2009, Faúndez and Carvajal 2014). All described species are terrestrial predators. Some species are considered beneficial to humans as these help control populations of agricultural pests. Several species of Nabis have been reported as biting humans (Faúndez 2015).

Within the Nabidae Arachnocoris is one of two genera in the tribe Arachnocorini. The arachnophilic genus ${ }^{5}$ Arachnocoris Scott is a small and little-known group of specialized kleptoparasitic nabids that spend their lifestages living in a relatively treacherous habitat, namely a spider's web, particularly non-sticky portions of it (Henry 1999; Mercado-Santiago-Blay 2015; Figure 1, this paper). Although one species, Arachnocoris panamensis

\footnotetext{
${ }^{1}$ Submitted on March 15, 2016. Accepted on April 27, 2016. Last revisions received on May 30, 2016.

${ }^{2}$ Corresponding author. United States Department of Agriculture, Forest Service-Rocky Mountain Research Station, 240 West Prospect Fort Collins, Colorado 80526 USA. E-mail: jmercado01@fs.fed.us

3 Department of Paleobiology, National Museum of Natural History, MRC-121, $10^{\text {th }}$ and Constitution Avenue, Washington, District of Columbia 20560 USA. Email: blayj@ si.edu

${ }^{4}$ Department of Life Sciences, Insects, The Natural History Museum, Cromwell Road, South Kensington, London, SW7 5BD England, United Kingdom. E-mail: m.webb@nhm.ac.uk

${ }^{5}$ While there are guidelines for the pronunciation of Latin names (Borror et al. 1989, p. 97), there is also variation on the practice of pronouncing those names. This holds true for many scientific names, including Arachnocoris, a name that we have heard pronounced (and authoritatively argued about in the listserver, Entomo-L) with emphasis on "no" [Arachnócoris] or on "co" [Arachnocóris]. Square brackets indicate pronunciation of the word inside, not a scientific name.
}

DOI: 10.9784/LEB4(1)Mercado.01

Electronically available on May 31, 2016. Mailed on May 31, 2016. 
(Distant), has been reported to parasitize spiders in the genera Acrosoma (Araneidae), Theridion (Theridiidae), and Uloborus (Uloboridae) (Myers 1925), most species of Arachnocoris for which a host is known, parasitize spiders in the family Pholcidae, commonly known as pholcids, daddy longleg spiders, or cellar spiders. The Pholcidae is one of the most diverse and commonly found webbuilding families worldwide, and West Indian fauna can show a high island endemism (Huber 2000). The West Indian Pholcidae hosting Arachnocoris build horizontal webs (Sewlal and Star 2008, 2009; Mercado and Santiago-Blay 2015). Arachnocoris species are not considered to be obligatory kleptoparasites of their spider hosts, due its presence on hostless webs (Sewlal and Starr 2008, 2009). The early myrmecomorphic immatures ${ }^{6}$ (i.e. resembling ants Figure 1a), later immature stages (Figure 1b), and the adults (Figure 2) of Arachnocoris obtain all their food from specimens captured on its host's webs, making Arachnocoris an indirect obligate kleptoparasite in its relationship with its spider host. More than one individual Arachnocoris can live on the same web. For instance, Bergroth (1899) states that A. simoni "lives in a family".

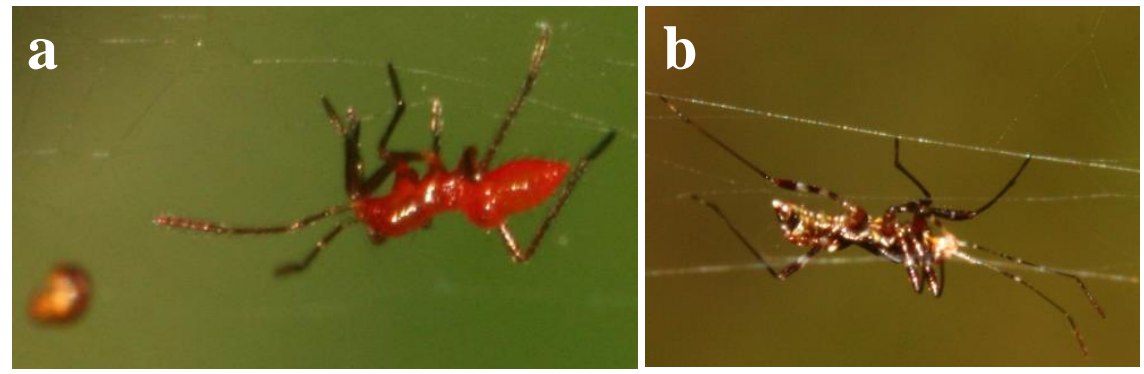

Figure 1. Immatures of Arachnocoris portoricensis n. sp. a). Early myrmecomorphic immatures present aposematic crimson red tagma, the legs and antennal segments mostly solid black. The structure resembling an egg (left) on a thread was not examined. Arachnocoris eggs remain undescribed. b). Late immature form moving on a pholcid's web. The specimens are illustrated upside down, as seen in nature. See Mercado and Santiago-Blay (2015) for more information on the biology of these insects. Photos by JEM.

Modifications suggesting the exclusivity of their arachnophilic life history habitat, include: 1) arched tarsal claws with smooth inner surfaces for sliding inversed over web strands (Lopez-Moncet ${ }^{7}$ 1990, 1997; Figure 1 in Mercado-

\footnotetext{
6 There are different usage preferences of the terms "larvae" and "nymphs" for immature exopterygote insects; thus, we have chosen the general term, "immature", to refer to these insect stages.

7 Papers written by Dr. André Lopez-Moncet have rendered his last name as Lopez or LopezMoncet. In this paper, we have consistently written Lopez-Moncet. As far as we know, it was Lopez-Moncet (1984) who first included scanning electron micrographs of Arachnocoris in
} 
Santiago-Blay 2015); 2) setiform parempodia aligned nearly parallel to tarsi possibly to sense the silk strands; 3 ) independent contraction of each claw as suggested by scanning electron microscopy (Lopez-Moncet 1990); and 4) the lack of typical surface attaching structures, such as tarsal surface adhering cushions (e.g., pulvilli, arolia) and features associated with the absence of a fossula spongiosa on their tibiae (Zhang et al. 2016), such as tenent hairs (setae).

The West Indian species of Arachnocoris were previously studied by Dr. Izyaslav M. Kerzhner (2007) in his review of West Indian Nabidae. These fascinating, Neotropical, spider-web dwellers are distributed from Panamá to Brazil and from Trinidad to the Greater Antillean islands of Puerto Rico and Hispaniola. The small and beautifully patterned species A. berytoides was beaten from vegetation on a cavity on the banks of a stream in Grenada, a habitat preferred by some pholcids. A similarly patterned but slightly larger species from the island of Guadeloupe, A. karukerae Lopez-Moncet, was synonymized with $A$. berytoides by Kerzhner (2007). As far as we are aware, Kerzhner's synonymy did not involve the examination of the type material of that species, which has been lost for years (Duvallet to Santiago-Blay, personal communication $\left.^{8}\right)$. Additionally, Kerzhner's synonymy of Puerto Rican specimens (Maldonado-Capriles and Navarro 1967) with A. berytoides, a species from Grenada, an island located more than $800 \mathrm{~km} \mathrm{SSE}$ away in the Caribbean archipelago, is questionable. We consider this since Kerzhner's synonymy suggests a broader distribution for A. berytoides than what is typically documented in other species in the genus (see Catalog). Before our work, thirteen species had been placed in this Neotropical genus (Volpi and Coscarón 2010, Coscarón and Volpi 2013), with the greatest diversity (i.e., nine species) described for tropical South America, particularly Brazil and Venezuela, as well as three species found from Costa Rica to Panamá.

The aim of this work is to review the West Indian species of Arachnocoris which Kerzhner (2007) placed under A. berytoides Uhler from Grenada, Guadeloupe, and Puerto Rico, and A. trinitatis Bergroth from Trinidad. Also, we aim to provide a simplified key to the species based on external characters which would be depicted in high definition imagery and to provide a catalog for

publications. His diverse scientific interests and large scientific production are highlighted in this link: Lopez and Lopez (no date).

${ }^{8}$ The following is a translation to English of a communication in French from Dr. Lopez-Moncet to Dr. G. Duvallet "The specimens of Arachnocoris had been transferred (25 years ago) from Beziers' Museum to the University of Montpellier, where Dr. Lopez had a desk at this time. It was to perform some SEM work on them. After that, Dr. Lopez retired from the University and the specimens were not transferred back to Beziers. The specimens are now all lost! Dr Lopez gives some precisions about the locality of capture of the specimens. It was in Basse Terre (Guadeloupe island[s]); the precise place was: Route de la Traversée, Maison de la Forêt, Sentier de découverte du milieu (Environment Discovery Track). The specimens were captured at the bottom of trees, between buttresses, on webs of the spiders Modisimus sp. (Pholcidae). Arachnocoris karukerae stay there immobile on the web. The Environment Discovery Track was in a protected area. Does it still exist?" 
all described species of Arachnocoris. We hope this work will stimulate further research about this fascinating group of the Nabidae.

\section{Methods}

The terminology in the descriptions follows that used by Schuh and Štys (1991) and Kerzhner (2007). All measurements were taken making sure the structures were perpendicular to the viewer and this also applies to the characters expressed on the dichotomous key. All measurements are given in millimeters $(\mathrm{mm})$ to the nearest decimal.

In rendering collecting data of material examined, one of us (JASB) used the backslash, /, to indicate a new line, the double backslash, //, to indicate a new label, and the square brackets, [ ], to indicate text added not present in the original label, so that the label is fully spelled out in the text of this paper.

\section{Depositories of Studied Specimens}

AMNH - American Museum of Natural History, New York, United States of America.

BMNH - British Museum of Natural History, London, England, United Kingdom.

MBBF - Musee du Biterrois, Beziers, France

NMNH - National Museum of Natural History (also known by the acronym, USNM) Smithsonian Institution, Washington District of Columbia, United States of America.

ZISP - Zoological Institute, St. Petersburg, Russia. This is the National Insect Collection of the former Union of Soviet Socialist Republics (USSR).

\section{Securing Specimens, Photomicroscopy, and Morphometrics}

Puerto Rico

New specimens from Puerto Rico, as well as specimens located at the NMNH were examined, first by author JEM, then by author JASB. These where photographed by JEM at the Rocky Mountain Research Station, Fort Collins, Colorado, USA and measured with a Leica MZ16 stereomicroscope fitted with a four mega pixel digital camera and the Leica Application Suite version 2.8 (Leica Microsystems, Inc.). Photo stacking was performed with Helicon Focus (HeliconSoft, Ltd., http://www.heliconsoft.com/). Image post-processing was performed on Adobe Photoshop CS4. Measurements were taken directly on Leica Application Suite, making sure the structure measured was as close to perpendicular as possible to the viewer.

\section{Hispaniola and Trinidad}

With the help of various colleges, coauthor JASB searched for specimens of Arachnocoris, at several museums, including AMNH, MBBF, Museum of Comparative Zoology (Harvard University, Cambridge, Massachusetts, USA), 
and NMNH. Specimens of Arachnocoris darlingtoni n. sp. from the Hispaniola were located and photographed at the AMNH with a Microptics imaging system. Photo stacking was performed with Helicon Focus. Image post-processing was performed on Adobe LightRoom 2.

\section{Grenada and Guadeloupe}

JEM and JASB consulted with numerous specialists in true bugs (Heteroptera) and spiders (Araneae) as well as biologists in Guadeloupe, Grenada, and France to locate additional specimens of Arachnocoris berytoides and A. karukerae. Unfortunately, curators of the Musee du Biterrois in France and colleagues who know that collection consider that all type material of $A$. karukerae is probably lost. No specimens of A. karukerae were located at Saint Petersburg University (Saint Petersburg, Russia), former affiliation of the late I. M. Kerzhner. The male holotype, as well as a male and an immature topotype of A. berytoides were examined and photographed by the third author (MDW). No additional museum material was located of these two species. Type specimens of $A$. berytoides were photographed at the BMNH, London, England, using a Leica stereo microscope with Canon EOS700D and Stemi SV11. These images were also studied by JEM and JASB.

\section{Scanning Electron Microscopy}

The backscattered electron images (Figures 11 and 15) were collected on uncoated samples in low vacuum mode on an FEI NovaNanoSEM 600 (Hillsboro, Oregon, USA) variable pressure field emission gun scanning electron microscope at the Department of Mineral Sciences, Smithsonian Institution. The images were collected at $10 \mathrm{kV}$ and about one nanoamp operating conditions. Images were further edited for a more pleasant balance of contrast and brightness using Adobe Photoshop CS2. Limitations on the amount of tilting possible with the microscope and our concern for the physical integrity of the specimens guided our decisions not to pursue some angles of view.

\section{Genitalia}

Features of the reproductive organs are often considered important in systematic zoology (e.g., for the Hemiptera, Faúndez and Carvajal 2014, Wygodzinsky 1952). The female terminalia has only been depicted from $A$. trinitatis (Kerzhner 2007). While the male genitalia, especially the parameres, of several species of Arachnocoris, including A. trinitatis, have been illustrated in more ocassions (e.g., China 1946, Kerzhner 1990, 2007), differences of the parameres do not always have species diagnostic power. For instance, in planthoppers (Hemiptera: Delphacidae) significant differences in the parameres have been reported between morphs of the same species (Galolo et al. 2011) and in water boatmen (Hemiptera: Corixidae), significant differences have been found between individuals of the same population (Savage and Feakes 1991). 
A male paratype of Arachnocoris portoricensis was available for dissection. In that specimen, the genital capsule was carefully removed from the rest of the body and placed in diluted, approximately $10 \%$, potassium hydroxide, $\mathrm{KOH}^{9}$ at room temperature. Some 72 hours later, the genital capsule was rinsed in distilled water and stored in a tiny shell ("genitalia") vial filled with $100 \%$ glycerine. Imaging was done with an Olympus DSX100 (Waltham, Massachusetts, USA) compound photomicroscope equipped with digital image focus stacking capabilities (Figure 12). Unfortunately, we did not secure permission to further image the male and female of $A$. darlingtoni with a scanning electron microscope that does not need metal-coating of the specimens.

\section{Systematic Entomology}

\section{Subfamily Nabinae Costa, 1855 \\ Tribe Arachnocorini Reuter, 1890 \\ Genus Arachnocoris Scott, 1881}

Arachnocoris Scott, 1881 The Entomologist's Monthly Magazine 17:272. Arachnocoris: Reuter, 1890 Revue d'entomologie 9:292.

Velidia: Uhler, 1894 Proceeding of the Zoological Society of London, p. 206.

Arachnocoris: Reuter, 1908 Mémoires de la Société Entomologique de Belgique 15:129.

Arachnocoris: Harris, 1928 Entomologica Americana 9(1-2):27.

Type Species: Arachnocoris albomaculatus Scott, 1881. 16 species.

Diagnosis: Habitus subelongate, cylindrical, small $(2.9-6.0 \mathrm{~mm}$ long). Head anteriorly declivous, short, sub-quadrate, as long as or shorter than first antennomere; compound eyes large, round, lower hind quadrant margin slightly pressed or emarginate, with one long seta from middle of the anterior margin; ocelli distinct, facing dorsad, between and close to rear margin of eyes; antennae four segmented, long, slender, often annulate with black, white, yellow, or red. Thorax: Prothoracic anterior lobe with a deep, central impression on basal margin; median lobe broad, trapezoidal, strongly convex, and anteriorly declivous; scutellum with a semi-erect, strong spine pointing apically; scent gland prominent; hemelytra narrow at middle, membrane round posteriorly, without distinct venation, macropterous ${ }^{10}$. Legs: elongate, femora sometimes

\footnotetext{
${ }^{9}$ We understand that Dr. Kerzhner's clearing protocol included $\mathrm{KOH}$ that had been heated with the flame he used to light his large cigars. He had the protocol timed perfectly, by gestalt.

${ }^{10}$ The morphological terms, macroptery, brachyptery, microptery, aptery, etc. refer to the size and other characteristics of the wings (Galbreath 1975, Slater 1975, Andersen 1982, Schuh and Slater 1995, Gorth and Headrick 2001, Fernández-Triana and Boudreault 2016). These and other descriptors are generally applied to the adult insect and, by extension, to the species and are used with the understanding that they apply to the maximal development of the wing in an individual or
} 
with dark annuli, pro- and mesofemora raptorial, with two ventral rows of spines on the broad femora; tibia slender, long as femora or longer, lacking fossula spongiosa; tarsal claws retractable and hooked with a smooth inner face (see Introduction). Abdomen: Hypodermic or traumatic insemination is required. Immature stages myrmecomorphic, sometimes aposematically colored (Mercado and Santiago-Blay 2015).

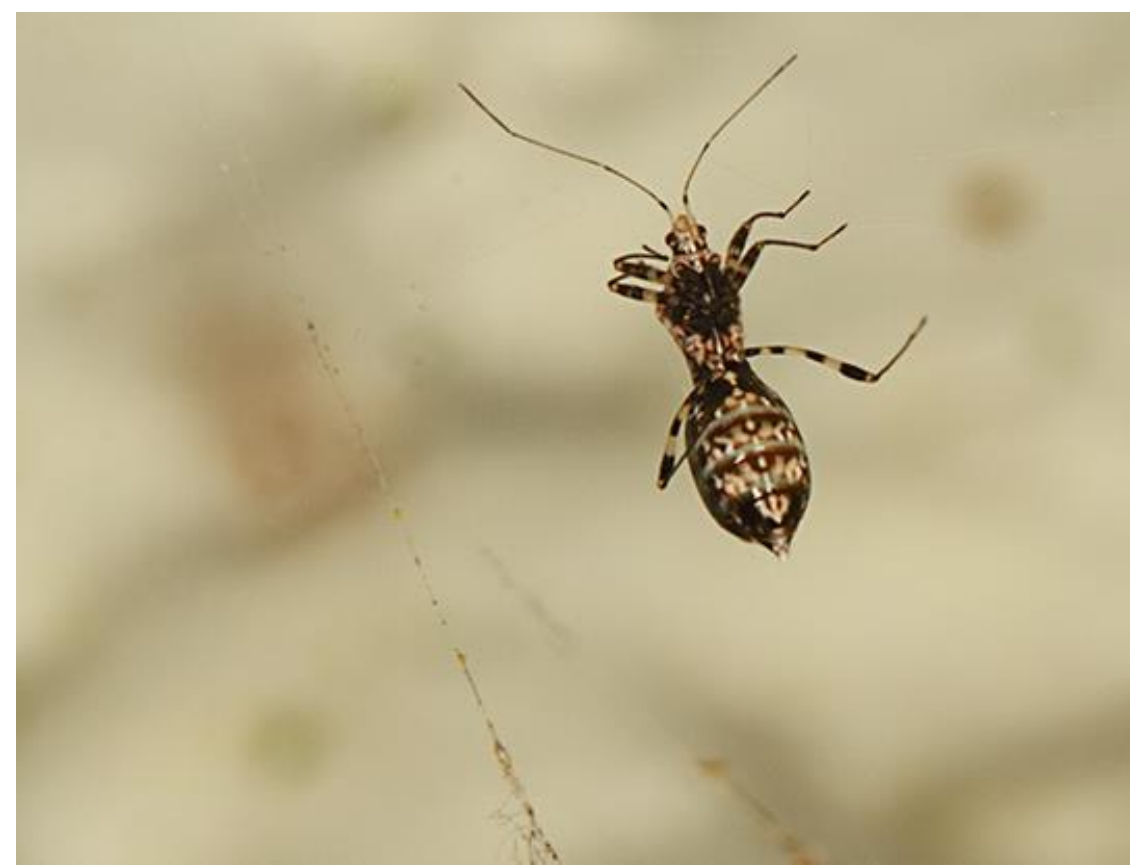

Figure 2. Adult female Arachnocoris portoricensis n. sp. on spider web. Mr. Alfredo D. Colón-Archilla gave permission to use this image of which he retains copyright.

on a species. Some species of insects are polymorphic, or polyphenic, for wing development (Kim and McPheron 1993, Sakashita et al. 1998, Simpson et al. 2011). The physiological term, volant, refers to the ability of an organism to fly. For instance, Sewlal and Starr (2008) reported evasive flight behavior in A. trinitatis, a volant species. Although macropterous insects have long wings and are generally volant, some are unable to fly as they may lack flight muscles (e.g., Socha and Šula 2006, Solbreck 1986). In contrast, brachypterous insects are generally non-volant, yet some may be able to fly if they have slightly reduced wings. Apterous insects cannot fly. Common usage of these terms may vary among different taxonomic groups. Environmental factors, such as photoperiod (Harada 1993, 1998; Honěk 1979; Musolin and Saulich 1996, Socha 2001), food quality (Solbreck 1986), high population density (Kim and McPheron 1993), etc. or genetics (Honěk 1995, Solbreck 1986) influence wing development. 


\section{Key to the West Indian Species of Arachnocoris}

1. First antennomere longer than head, lacking bands (Figure 3a); profemora not annulate (Figure 4a); total body length $4.00-4.80 \mathrm{~mm}$ Trinidad, Venezuela A. trinitatis Bergroth

- First antennomere shorter than head, banded; profemora with dark annuli; smaller, total body length $2.85-3.60 \mathrm{~mm}$

2. Base of first antennomere reddish brown (Figure 3b); abdomen strongly constricted at base; total body length $3.60 \mathrm{~mm}$; Guadeloupe A. karukerae Lopez-Moncet

- Base of first antennomere whitish; abdomen not constricted at base; smaller, total body length 2.85 to $3.08 \mathrm{~mm}$ 3

3. Antennomeres II-III grayish; IV darker, lacking bands (Figure 3d); femora brownish medially (Figure 4d); Puerto Rico A. portoricensis, n. sp.

- Antennomere II medially lighter than III; IV darker, with an ivory band at middle (Figures $3 \mathrm{c}$, e); all femora lighter medially

4. Median one fourth of antennomere IV ivory (Figure 3e); anterior lobe of pronotum dark brown, shagreened, dull, densely setose; male's last ventrite of male yellowish (Figure 8); Hispaniola A. darlingtoni, n. sp.

- Median one sixth of antennomere IV ivory (Figure 3c); anterior lobe of pronotum reddish, smooth, glossy, sparsely setose; last ventrite of male dark brown (Figure 5, lower left corner); Grenada A. berytoides (Uhler) 


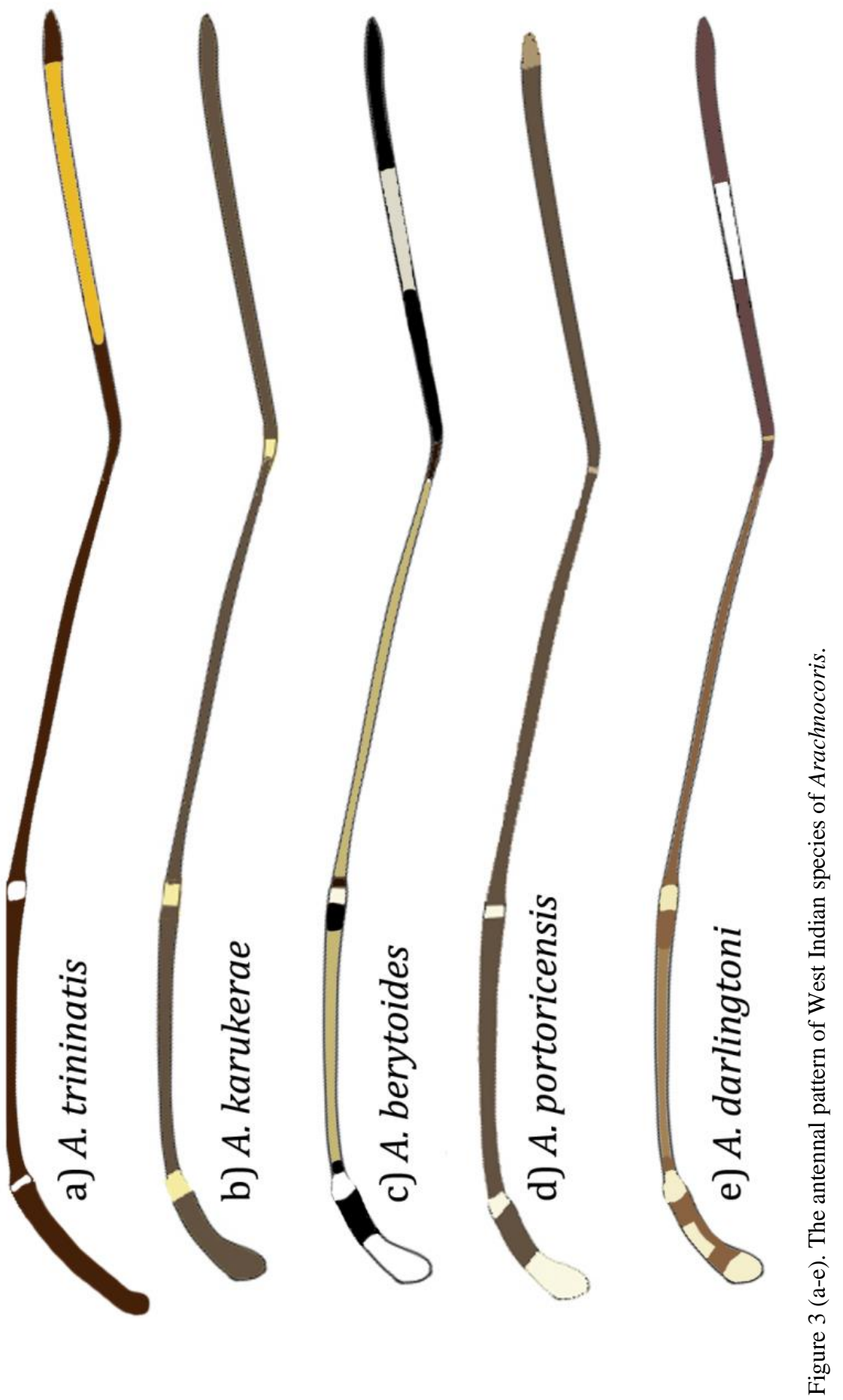



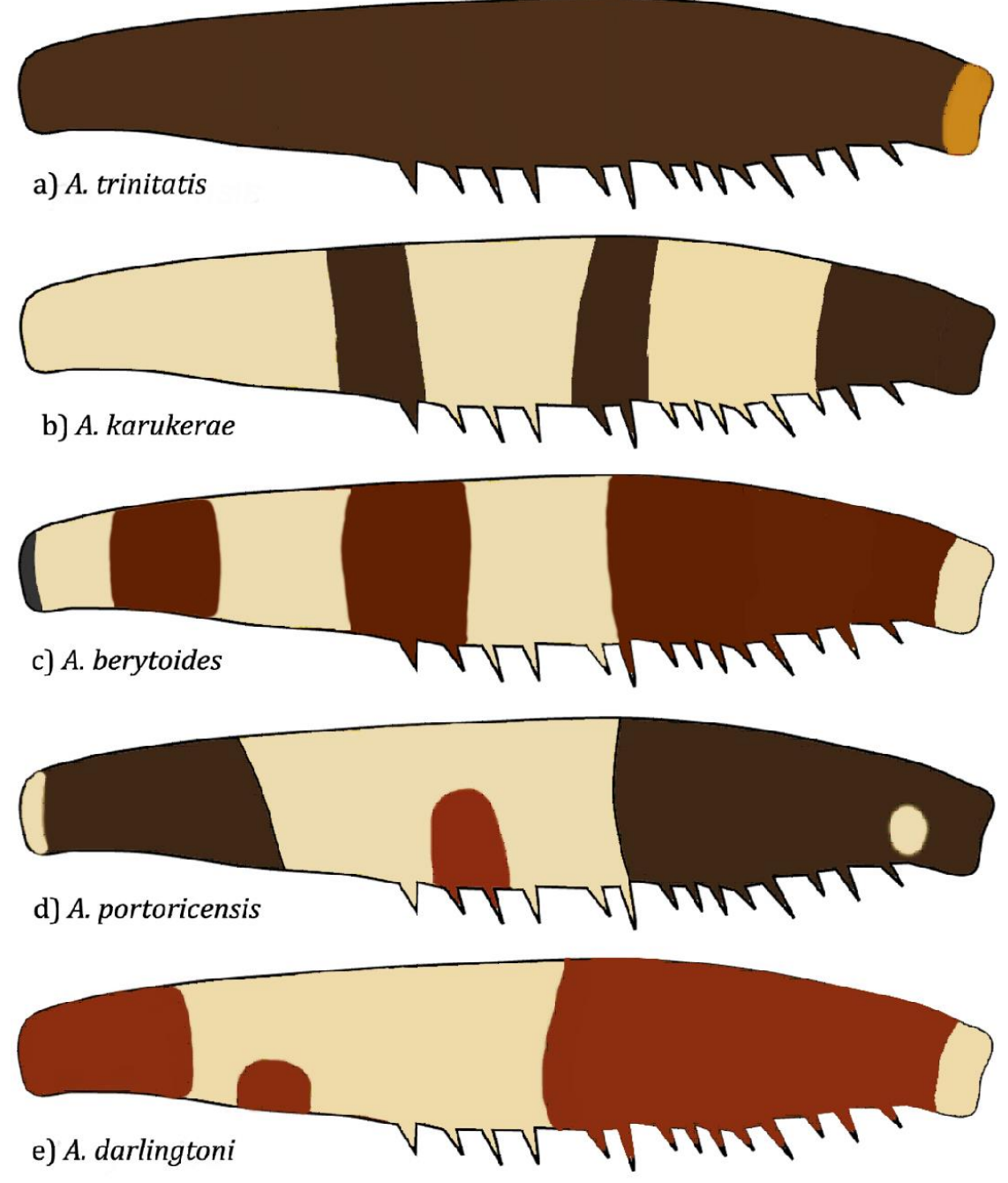

Figure 4 (a-e). The femoral pattern of West Indian species of Arachnocoris. 


\section{Species Descriptions}

\section{Arachnocoris berytoides (Uhler, 1894)}

(Figures 3c, 4c, and 5)

Velidia berytoides Uhler, 1894:207; Bergroth, 1914:116; Costa-Lima, 1927:541; Maldonado-Capriles and Navarro, 1967:49; Woodruff et al., 1998: 93.

Arachnocoris berytoides: Bergroth, 1914:116; Costa-Lima, 1927:541; Harris, 1928:28; Lopez-Moncet, 1984:3; Lopez-Moncet, 1997:531; Kerzhner, 2007:229-230; Volpi and Coscarón, 2010: 52; Coscarón and Volpi, 2013:52.

Type material examined: Holotype male: Grenada (Windward side), Balthazar, 27.iv., alt. 250', Shady bank of stream in second growth. Beaten from a mass of bush and decaying leaves, H. H. Smith, BMNH 1895-206, BMNH(E) 1705804.

Other material examined: One topotypic male, same data as for holotype except, 22.v. "Second growth by stream. Among dry withered leaves on bush". BMNH(E) 1705805. One topotypic immature, same data as holotype except, 22.v. "Second growth thicket by stream. Among withered leaves in cavity of a bank". BMNH(E) 1705806. All specimens are deposited at BMNH.

Distribution: Grenada (West Indies).

Spider Host: Unknown.

Diagnosis. Distinguished from A. trinitatis and A. karukerae by its smaller size and lack of a constricted abdominal base. From A. portoricensis, it is distinguished by the ivory band on fourth antennomere (Figure $3 \mathrm{c}$ ) and from $A$. darlingtoni by that same band being narrower as well as the dark brown and glossy anterior pronotal lobe (Figure 5).

Description (Based on type material) Head: glossy, dark brown with a light brown line from ocelli to posterior margin of compound eye, between eyes and an incomplete median line just posterior of ocelli to about anterior margin of compound eyes; antennomeres I - II ivory, with subapical brown annuli, III light brown with brown apical and basal tips, IV dark reddish brown, annulate on mid-length with ivory; rostral segments and gena yellowish. Thorax: Pronotal collar glossy, yellowish to light brown; anterior lobe dark brown, glossy with a thin ivory- colored carina at the outer margins, and a deep median groove; posterior lobe grayish brown, strongly punctate, humeri with a small whitish callosity in the angle, intrahumeral and posterior border black, with yellowish margin; pleurites maculate, pale yellow; scutellum grayish yellow, with ivory 
apical spine, setae present. Legs: profemora whitish, with wide subapical reddish brown band, meso- and metafemora marked with three reddish brown bands delimiting four whitish bands; tibial apex and tarsi also reddish brown. Abdomen: Male - ventrally dull, segments brown, except two anterior to last yellow, two anterior to yellow pair with three yellow spots. Female - unknown.

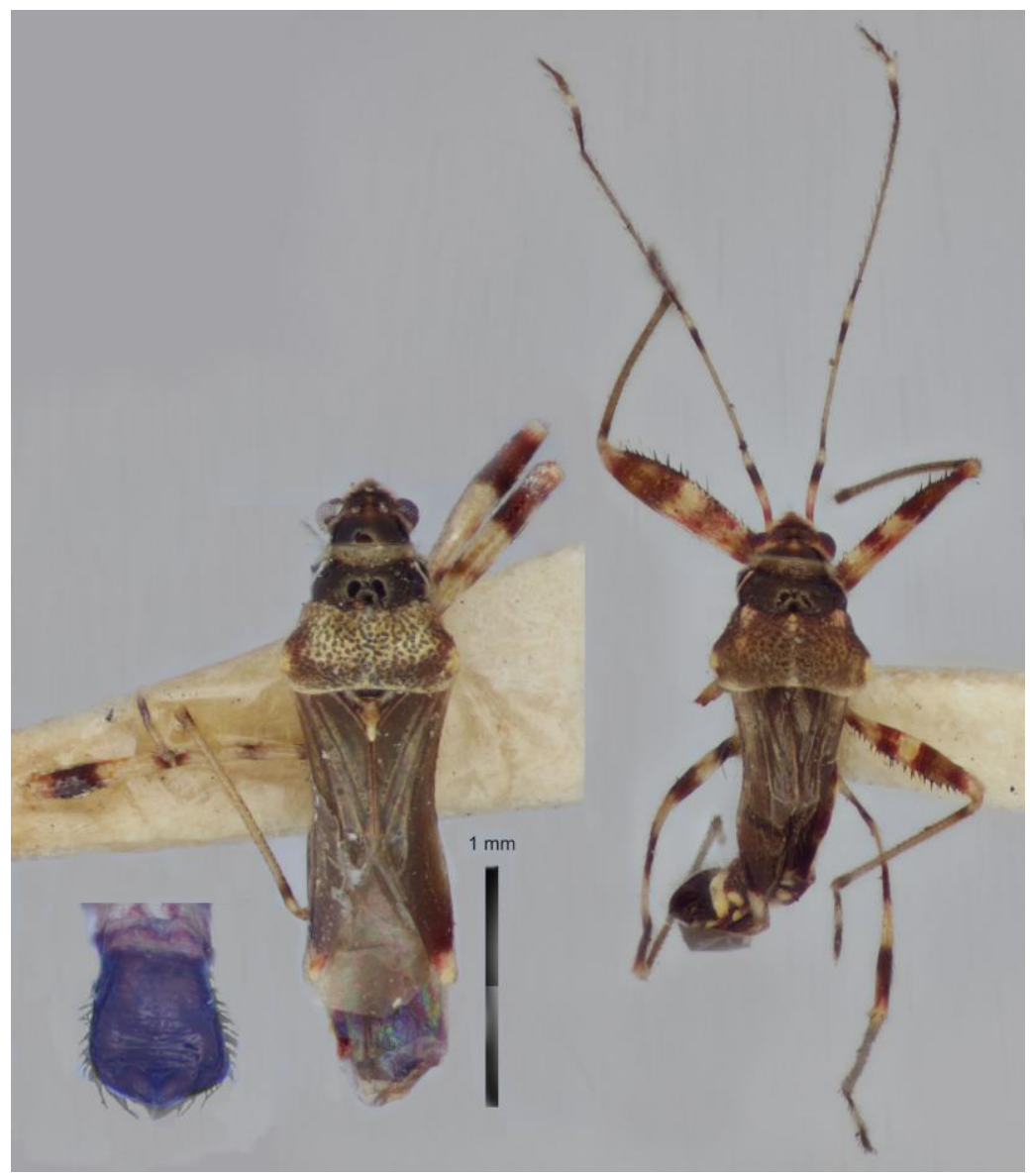

Figure 5. Arachnocoris berytoides (Uhler, 1894) male holotype dorsal habitus (left) and a male topotype (right). Ventral view of topotype's abdomen shown on the bottom left corner. Scale bar $=1 \mathrm{~mm}$.

Morphometrics (Adapted from Kerzhner 2007): Male - Total length $2.9 \mathrm{~mm}$. Length of antennomere I - $0.4 \mathrm{~mm}$, II - $0.7 \mathrm{~mm}$, III - $0.8 \mathrm{~mm}$; IV - $0.6 \mathrm{~mm}$. Head width $0.4 \mathrm{~mm}$, at vertex $0.2 \mathrm{~mm}$. Length of antennomere I $-0.2 \mathrm{~mm}$, II -0.4 $\mathrm{mm}$, III - $0.4 \mathrm{~mm}$; IV - $0.2 \mathrm{~mm}$. Length of rostral segment I - $0.2 \mathrm{~mm}$, II - 0.4 
$\mathrm{mm}$, III - $0.3 \mathrm{~mm}$, IV $-0.2 \mathrm{~mm}$. Pronotal length $0.6 \mathrm{~mm}$ (including collar 0.1 $\mathrm{mm}$, anterior $0.2 \mathrm{~mm}$ and posterior lobe $0.2 \mathrm{~mm}$ ); width at collar $0.4 \mathrm{~mm}$, at humeri $0.8 \mathrm{~mm}$. Scutellum width $0.3 \mathrm{~mm}$, length $0.2 \mathrm{~mm}$. Profemora length 1.1 $\mathrm{mm}$; mesofemora $1.0 \mathrm{~mm}$; metafemora $1.2 \mathrm{~mm}$. Female - unknown.

Remarks: In the original description of this species, only one specimen was mentioned yet two other specimens (one male and one immature) with almost the same data are deposited in the BMNH collection (see section Other material examined). In examining the holotype and the topotypical adult, Kerzhner (2007) indicated their sex to be male but the sex of the holotype cannot be verified due to the damage of its terminalia. Unaccountably, the color pattern of the antennae and femora (used to distinguish species in this genus) of the above specimens, do not match their description in previous works and similarly the length ratios of antennomeres II to IV of the adults do not agree with those reported by Kerzhner (2007).

Remarks: In the original description of this species, only one specimen was mentioned yet two other specimens (one male and one immature) with almost the same data are deposited in the BMNH collection (see section Other material examined). In examining the holotype and the topotypical adult, Kerzhner (2007) indicated their sex to be male but the sex of the holotype cannot be verified due to the damage of its terminalia. Unaccountably, the color pattern of the antennae and femora (used to distinguish species in this genus) of the above specimens, do not match their description in previous works and similarly the length ratios of antennomeres II to IV of the adults do not agree with those reported by Kerzhner (2007).

\section{Arachnocoris darlingtoni Santiago-Blay and Mercado, new species}

(Figures 3e, 4e, and 6-8)

Type material examined: Holotype male (VI-1938), collected in Sánchez [Samaná Province], Dom.[imican] Rep.[ublic] by [P. J.] Darlington and female paratype (same data as holotype). Although both specimens are deposited at AMNH, they carry a label that reads, "Museum of Comparative Zoology (MCZ)", Harvard University. In the late 1960's there was an exchange of the entire MCZ Heteroptera collection for a synoptic collection of identified Heteroptera supplied by the AMNH (Schuh to Santiago-Blay, personal communication).

Distribution: Dominican Republic (Hispaniola, West Indies).

Spider Host: Undetermined. 
Additional material examined: None could be located.

Diagnosis. Arachnocoris darlingtoni is distinguished from A. trinitatis by its banded antennae and legs (Figures $3 \mathrm{e}$ and $4 \mathrm{e}$ ), and from $A$. karukerae, by the unconstricted abdominal base, the smaller size, and the banded antennomeres. From A. portoricensis, it differs by its overall lighter background color, the by lighter antennomeres II and III, the median dark band on antennomere I that is interrupted on the upper side and by the lack of light anteroventral spots on the profemoral apex (Figures 4e and 6-8). From A. berytoides, which has similar antennal banding, it differs by the shagreened prothorax with dark areas being reddish and not brownish (Figure 6).

Description (Based on type material) Head: ventrally yellowish, dorsally mostly brownish red with lighter marginal narrow band behind compound eyes, extending to outer margin of ocelli, an ivory area anterior margin of eyes extends in front of antennal insertion area; compound eyes dark reddish brown to reddish brown; ocelli dark reddish brown, distance from eye $1.5 \mathrm{X}$ and $2.5 \mathrm{X}$ from other ocellus; rostral segment I yellowish brown rest ivory, II ivory with subapical dark brown annulus $1 / 3$ its length, III and IV dark brown; antennomere I yellowish with a broad (2/3 its length) median dark brown band interrupted dorsad and laterad with yellowish area; II yellowish brown medially with dark brown annulus basally, a subapical dark brown band (1/5 its length), and a narrow yellowish annulus apically; III yellowish brown with basal yellowish annulus; IV brownish red with whitish median band, 1/3 its length. Thorax: Pronotal collar yellowish brown, finely punctate, setose; anterior lobe cupraceous, finely punctated, setose, outer margin with raised yellowish costae, setose, medially impression on posterior margin; posterior lobe strongly convex, setose, coarsely punctate posterolateral margin raised; scutellum dark brown with a yellowish Y-shaped mark rising posteriorly into a spine, setae present. Wings: Hemelytra hyaline with darker bands on apical edge, distal area of corium orange red, with whitish apical portion. Legs: Pro- and mesocoxae brownish red, metacoxae yellowish with a reddish brown macula anterolaterally; trochanters brownish red; femora brownish red with one median yellowish band on pro- and two on meso- and metafemora dorsally, ventrally profemora median band divided into two by brownish red incomplete band, all femora with pale yellow annuli at base and apex, I - II with two ventral rows of spines; tibiae yellowish brown, as long as femora but $1 / 4$ the thickness of both pro- and mesofemora and $1 / 3$ as thick as metafemora; metatarsi brownish red, second segment with whitish apical half. Abdomen: Male - ventral surfaces largely mottled by reddish brown and pale yellow maculate; ventrites brownish red laterally except V that is pale yellow maculate; ventrite VII with 7-toothed lobe, apical extremes bulging into two yellowish raised cusps. Female - ventral coloration slightly lighter than the male, ventrite VI longer than in male with a 
yellowish apical pointing "spade"-shaped spot ending on a single raised cusp; gonocoxae yellow ending close to anal opening, anterior area of anal opening yellow.

Morphometrics: Male - Total length $2.9 \mathrm{~mm}$. Head length $0.2 \mathrm{~mm}$, width at eye level $0.4 \mathrm{~mm}$, at vertex $0.2 \mathrm{~mm}$, at base $0.3 \mathrm{~mm}$. Distance between ocelli 0.1 $\mathrm{mm}$, between ocelli and eye $0.04 \mathrm{~mm}$. Length of antennal segment I $-0.2 \mathrm{~mm}$, II - $0.6 \mathrm{~mm}$, III - $0.9 \mathrm{~mm}$; IV- $0.5 \mathrm{~mm}$. Length of rostral segment I - $0.3 \mathrm{~mm}$, II $0.4 \mathrm{~mm}$, III - $0.3 \mathrm{~mm}$, IV- $0.2 \mathrm{~mm}$. Pronotal length $0.6 \mathrm{~mm}$ (including collar 0.1 $\mathrm{mm}$, anterior $0.1 \mathrm{~mm}$ and posterior lobe $0.3 \mathrm{~mm}$ ); width at collar $0.4 \mathrm{~mm}$, at anterior lobe margin $0.6 \mathrm{~mm}$, at humeri $0.8 \mathrm{~mm}$. Scutellum width $0.4 \mathrm{~mm}$, length $0.3 \mathrm{~mm}$. Profemora length $0.8 \mathrm{~mm}$, protibia $0.9 \mathrm{~mm}$, protarsi 0.2 (claws unavailable); mesofemora $1.0 \mathrm{~mm}$, mesotibia $1.1 \mathrm{~mm}$, mesotarsi $0.3 \mathrm{~mm}$ (claws unavailable); metafemora $1.0 \mathrm{~mm}$, metatibia $1.5 \mathrm{~mm}$, metatarsi $0.3 \mathrm{~mm}(0.4$ $\mathrm{mm}$, including claws). Female - Total length $3.0 \mathrm{~mm}$. Head length $0.2 \mathrm{~mm}$, width at eye level $0.4 \mathrm{~mm}$, at vertex $0.2 \mathrm{~mm}$, at base $0.3 \mathrm{~mm}$. Distance between ocelli $0.1 \mathrm{~mm}$, between ocelli and eye $0.1 \mathrm{~mm}$. Length of antennomere I - 0.2 $\mathrm{mm}$, II - $0.5 \mathrm{~mm}$, III $-0.8 \mathrm{~mm}$, IV $-0.5 \mathrm{~mm}$. Length of rostral segment I - 0.2 $\mathrm{mm}$, II - $0.4 \mathrm{~mm}$, III - $0.4 \mathrm{~mm}$, IV - $0.1 \mathrm{~mm}$. Male - Pronotum $0.6 \mathrm{~mm}$ long (including collar $0.1 \mathrm{~mm}$, anterior $0.1 \mathrm{~mm}$ and posterior lobe $0.4 \mathrm{~mm}$ ); width at collar $0.4 \mathrm{~mm}$, at anterior lobe margin $0.6 \mathrm{~mm}$, at humeri $0.8 \mathrm{~mm}$. Scutellum width $0.3 \mathrm{~mm}$, length $0.3 \mathrm{~mm}$. Profemora length $1.1 \mathrm{~mm}$, protibia $1.1 \mathrm{~mm}$, protarsi $0.3(0.4 \mathrm{~mm}$, including claws $)$; mesofemora $1.0 \mathrm{~mm}$, mesotibia $1.1 \mathrm{~mm}$, mesotarsi 0.4 (0.4 mm including claws); metafemora $1.3 \mathrm{~mm}$, metatibia $1.7 \mathrm{~mm}$, metatarsi 0.4 (0.5 mm including claws).
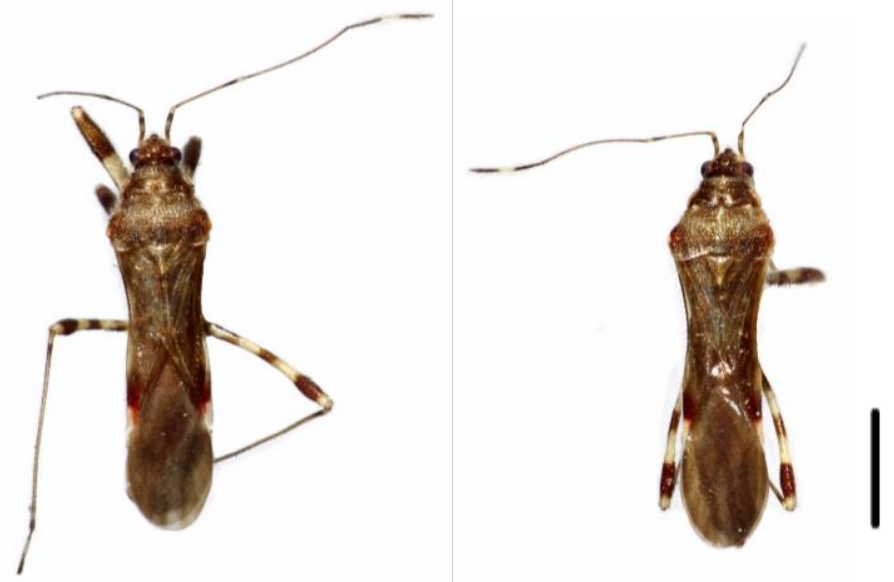

Figure 6. Dorsal habitus of Arachnocoris darlingtoni n. sp. Male holotype (left) and female paratype (right). Scale bar $=1 \mathrm{~mm}$. 
Etymology: Named after its collector, the zoogeographer Dr. Phillip Jackson Darlington, Jr. (Museum of Comparative Zoology, Harvard University).
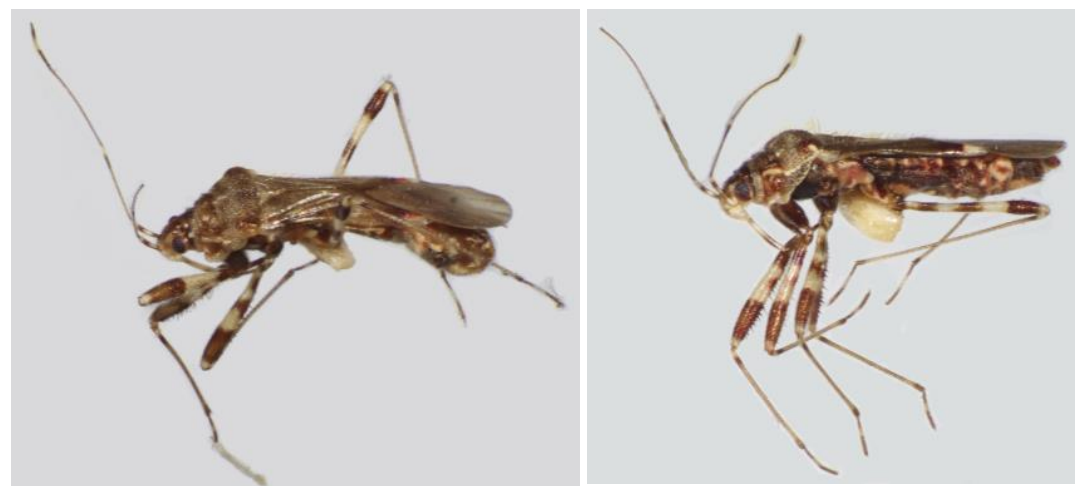

Figure 7. Lateral habitus of Arachnocoris darlingtoni n. sp. male holotype (left) and female paratype (right).
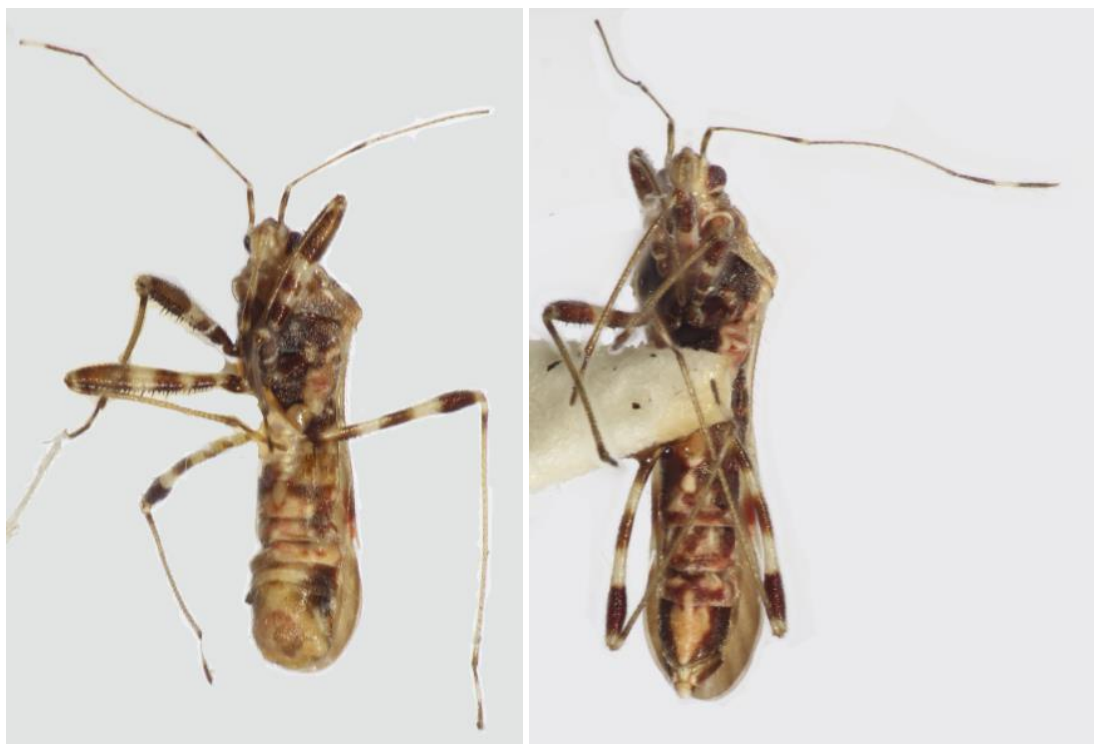

Figure 8. Ventral habitus of Arachnocoris darlingtoni n. sp. male holotype (left) and female paratype (right). 


\section{Arachnocoris karukerae Lopez-Moncet, 1990}

(Figures $3 \mathrm{~b}$ and $4 \mathrm{~b}$ )

Arachnocoris n. sp. Lopez-Moncet, 1984:3 (two figures, p. 4).

Arachnocoris karukerae Lopez-Moncet, 1990:3 (eight figures, pp. 6-7); Lopez-

Moncet, 1997:528; Volpi and Coscarón, 2010: 52.

A. berytoides: Kerzhner, 2007:229 [synonymized in error].

A. berytoides: Coscarón and Volpi, 2013:94.

Type Material: Holotype female; paratypes, five females (MBBF) Primary forest near the "Maison de la Forêt" Crossing the (D 23 [La route de la Traversée]) road, central Basse Terre, Guadeloupe. On the webs built by a Pholcidae spider (Modisimus sp. but read comments on Catalog) between the buttresses at the base of large tree, (August 1983 [Collector] A. Lopez). Type material is presumably lost (see Remarks, below).

Distribution: Guadeloupe (unconfirmed from Martinique, West Indies).

Spider Host: Mecolaesthus taino Huber (Araneae: Pholcidae)

Other material examined: None.

Diagnosis. Arachnocoris karukerae can be distinguished from A. trinitatis by its smaller size and banded femora (Figure $4 b$ ). From the geographically close species, A. berytoides by its larger size and by the medially unhanded antennomere IV (Figure $3 b$ ). It differs from A. portoricensis and A. darlingtoni by the brown base of antennomere I (Figure $3 b$ ).

Description (Adapted from Lopez-Moncet, 1990.) Head smooth, glossy, yellowish on the sides and underside, dark brown basally and on a trapezoidal area between the antennae; eyes dark brown to reddish brown; ocelli dark brown; rostrum with a dark brown tip; antennae slender, thread-like, all segments with yellowish-brown joints. Thorax: Pronotum collar narrow, smooth, light brown, pubescent; median lobe smooth, dark brown, almost glabrous, with a central depression and reflexed edges; posterior lobe broad, convex, setose, densely punctate, shagreened; mesonotum (visible beneath pronotum) dark brown, with paramedian, longitudinal, yellowish stripes; scutellum dark brown, without whitish macula, with two strong, erect bristles; sternites uniformly glossy dark brown on prothorax and mesothorax, with two different bands on metathorax; pleurites glossy dark brown on mesothorax, yellowish on metathorax; integument just above hind coxa (III) with a special microsculpture expanding to form an auricle that accommodates opening of a scent gland, only visible with SEM; hemelytra rather dull, without metallic 
sheen, reaching end abdomen, clavus dark brown, corium with an obvious orange-red spot followed by an ivory macula, before corium widens; membrane darker in center and around edges; membranous wings, slightly iridescent. Legs: Coxae I and II dark brown, posterior pair (III) yellowish, with one or two reddish brown macula on prolateral surface; trochanters dark brown; femora with dark brown annuli (apical widest), which define three clear areas on first pair (I) and four on other two (II and III); hind femora (III) unarmed, femora I and II with black spines aligned in two contiguous rows; tibia and tarsi dark brown; tarsal claws short and straight. Abdomen: Female - dorsal surface yellowish to reddish brown; ventrally convex, yellowish, largely mottled brown or brownish red, maculae, semi-aligned, not joining on midline, or transverse stripes mottled with lighter areas; some raised yellowish cusps present. Male unknown.

Morphometrics: Female - Total length, $3.6 \mathrm{~mm}$, head $0.4 \mathrm{~mm}$ long, thorax, 1 $4 \mathrm{~mm}$ long, abdomen $1.8 \mathrm{~mm}$ long; pronotal lobe $0.9 \mathrm{~mm}$ wide. Male unknown.

Remarks: All type material of A. karukerae was determined lost by curators of MBBF. In spite of extensive efforts, no additional specimens of A. karukerae could be garnered and no further specimens are known to the authors.

\section{Arachnocoris portoricensis Mercado, new species}

(Figures 3d, 4d, and 9-12)

Velidia berytoides Maldonado-Capriles and Navarro 1967:49.

Arachnocoris berytoides Kerzhner 2007:229; Volpi and Coscarón 2010:52.

Distribution: Puerto Rico (West Indies), this paper.

Spider Host: Modisimus signatus Banks (Araneae: Pholcidae), other species of Pholcidae

Type Material: Holotype, male, Caimitillo tr[ail], Río Grande, Puerto Rico, R[oad] 191 El Yunque N[ational] F[orest], 200 m, III-20-2012; on Pholcidae web, collected by J. E. Mercado (Figure 1) . Four paratypes: One male and one female with same collecting data as holotype (Figure 9). Male (dissected) and female. Puerto Rico: Luquillo/ E[x]p[erimental] Forest, R[ou]t.[e] 191, Coca Falls, 14 June/ 1990, A[.] G[.] Wheeler, Jr. / Taken in dead ferns. All deposited at $\mathrm{NMNH}$.

Diagnosis. Distinguished from A. trinitatis by the smaller size; from $A$. karukerae by the smaller size and the light basal two-thirds of the first 
antennomere (Figure 3d), and the unconstricted abdominal base. Arachnocoris portoricensis is distinguished from A. berytoides and A. darlingtoni by the medially unbanded antennomere IV (Figure 3d) and by two light anteroventral spots subapically on profemora (Figure 4d).

Description. Head: Dorsal basal half mostly dark brown, with a yellowish marginal line behind compound eyes extending to outside margin of ocelli; vertex with three short, yellowish lines between eyes, one central running anteroposteriorly, two laterals in a 45 angle anterolaterally from an eye to middle of vertex; apical half yellowish, except for a small dark brown spot on frons, and underside of head; compound eyes orange red; ocelli orange red to reddish brown; rostrum segment I yellowish, II yellowish with dark brown subapical annulus, III and IV dark brown; antennomere I basal two thirds yellowish, followed anteriorly by a dark brown band ending near grayish yellow apex, antennomeres II-IV grayish yellow apically, fourth also bearing setae three times longer than thickness of segment. Thorax: pronotal collar light yellowish brown, impunctate; anterior lobe dark brown, impunctate, outer margin with raised yellowish costae, with a deep depression at center of posterior margin having setae; posterior lobe strongly convex, densely punctate with raised costae at humeri; scutellum dark brown with a yellowish Y-shaped mark rising posteriorly into a spine, setae present; hemelytra mostly hyaline with darker bands on apical edge, lacking venation, distal area of corium orange red, with apex whitish. Legs: pro- and mesocoxae dark reddish brown, metacoxae yellowish, with a reddish brown macula anterolaterally; trochanters reddish brown; femora yellowish annulate, with dark bands, profemora with basal tip yellowish, sub-basal fifth dark brown, middle third yellowish with a reddish brown, narrow, central band, apical third dark brown, bearing a yellowish spot on outer side just distal of middle; femora II and III with a dark band covering apical fourth, followed toward base by three alternating yellowish and dark brown narrower bands: I and II with two ventral rows of spines, III unarmed; tibia grayish brown, as long as femora, a fourth the thickness of both pro- and mesofemora and a third as thick as metafemora; second metatarsal segment ivory, all others black. Abdomen: Female. Ventral surfaces mottled reddish brown, with yellowish maculae; laterotergites I, VI, and VII black except dorsally; laterotergites II-V mottled with reddish brown and yellowish maculae, $\mathrm{V}$ and VI only dorsally; laterotergite VII, containing the sexual structures, longest; gonocoxae yellowish, ending close to anal opening, anterior area of anal opening yellowish. Male. Ventral surfaces largely mottled with reddish brown and yellowish maculae. Laterotergites II, VII and VIII black except at the top of venter. Laterotergites III-VI mottled with reddish brown and yellowish maculae, VI and VII only dorsally. Lateral folds on tergite VII with 12 to 14 sclerotized denticles (Figure 12b). Laterotergite VIII longest, with reproductive structures, with two rounded apical lobes to hold the muscles of the paramere. Parameres 
sickle shape with a single apical inward point; similar to that of A. setosus (see Kerzhner1990). Setae visible on external paramere base which is posteriorly flattened. Phallus not extracted for examination but appears to have a pair of sclerotized spiculi on the innermost end (Figure 12a), this structure was described from A. trinitatis (Kerzhner 2007).

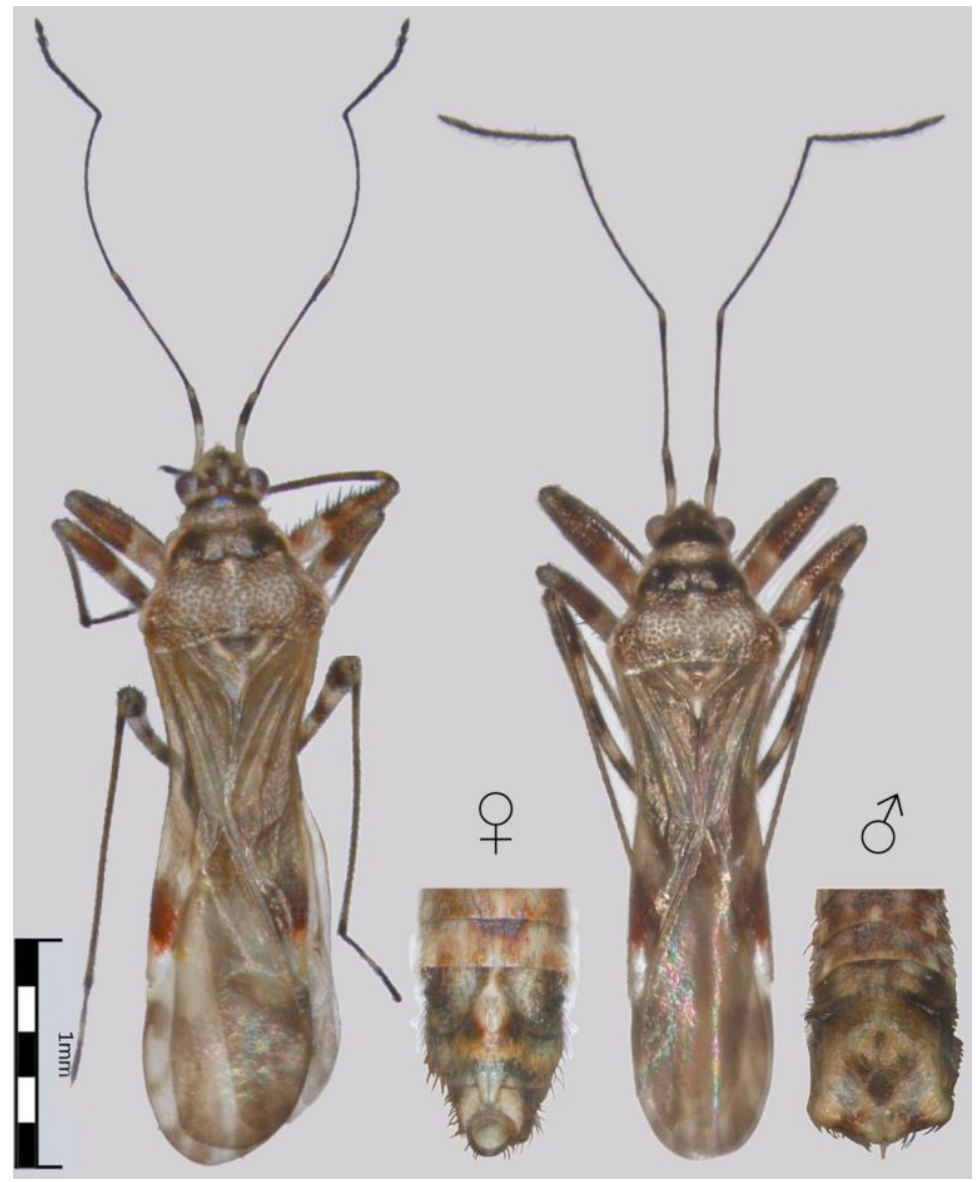

Figure 9. Dorsal habitus and ventrites of Arachnocoris portoricensis n. sp. female paratype (left) and male holotype (right). Scale bar $=1 \mathrm{~mm}$. 


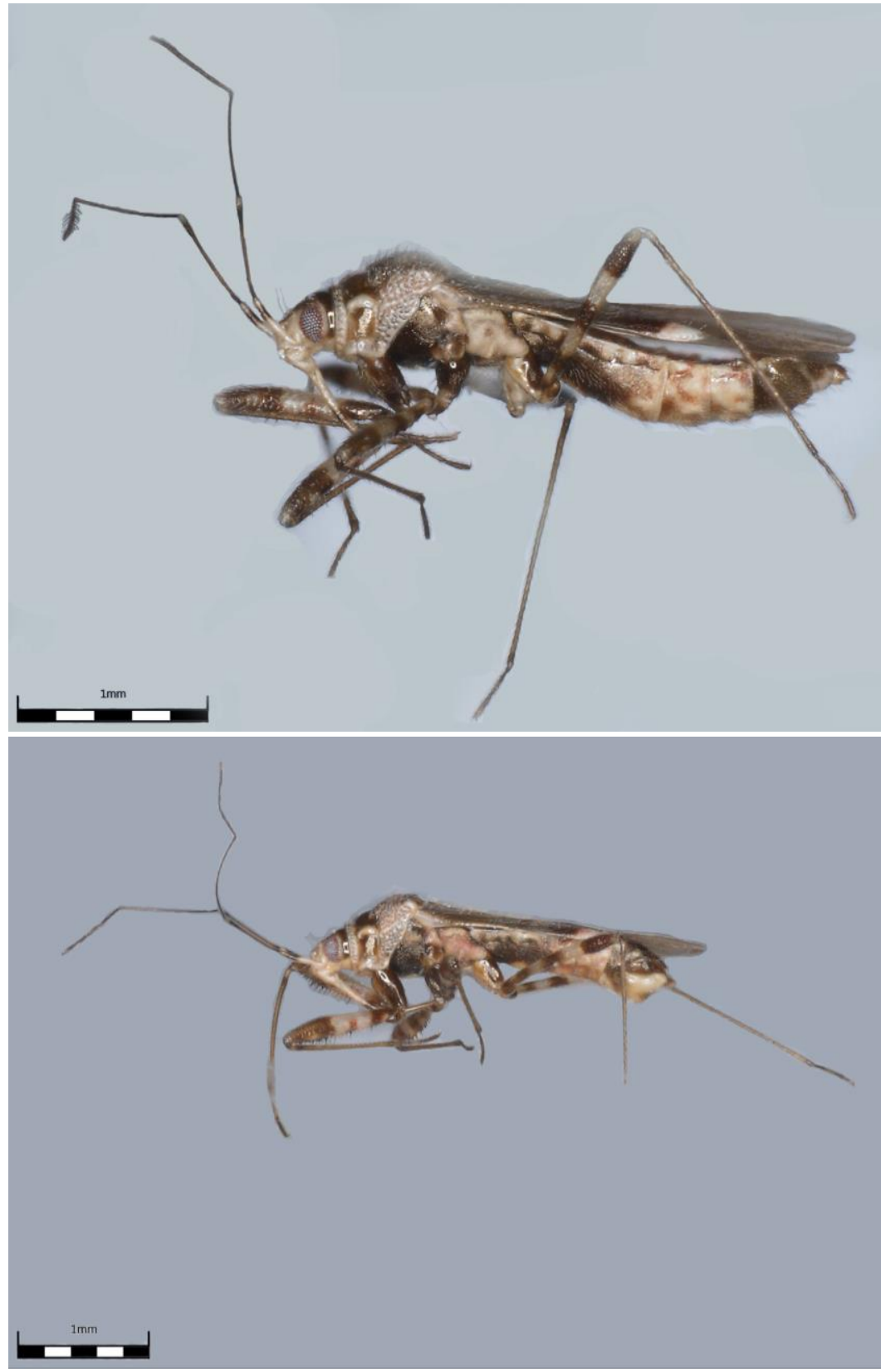

Figure 10. Lateral habitus of Arachnocoris portoricensis n. sp. female paratype (top) and male paratype (bottom, male). Scale bars $=1 \mathrm{~mm}$. 

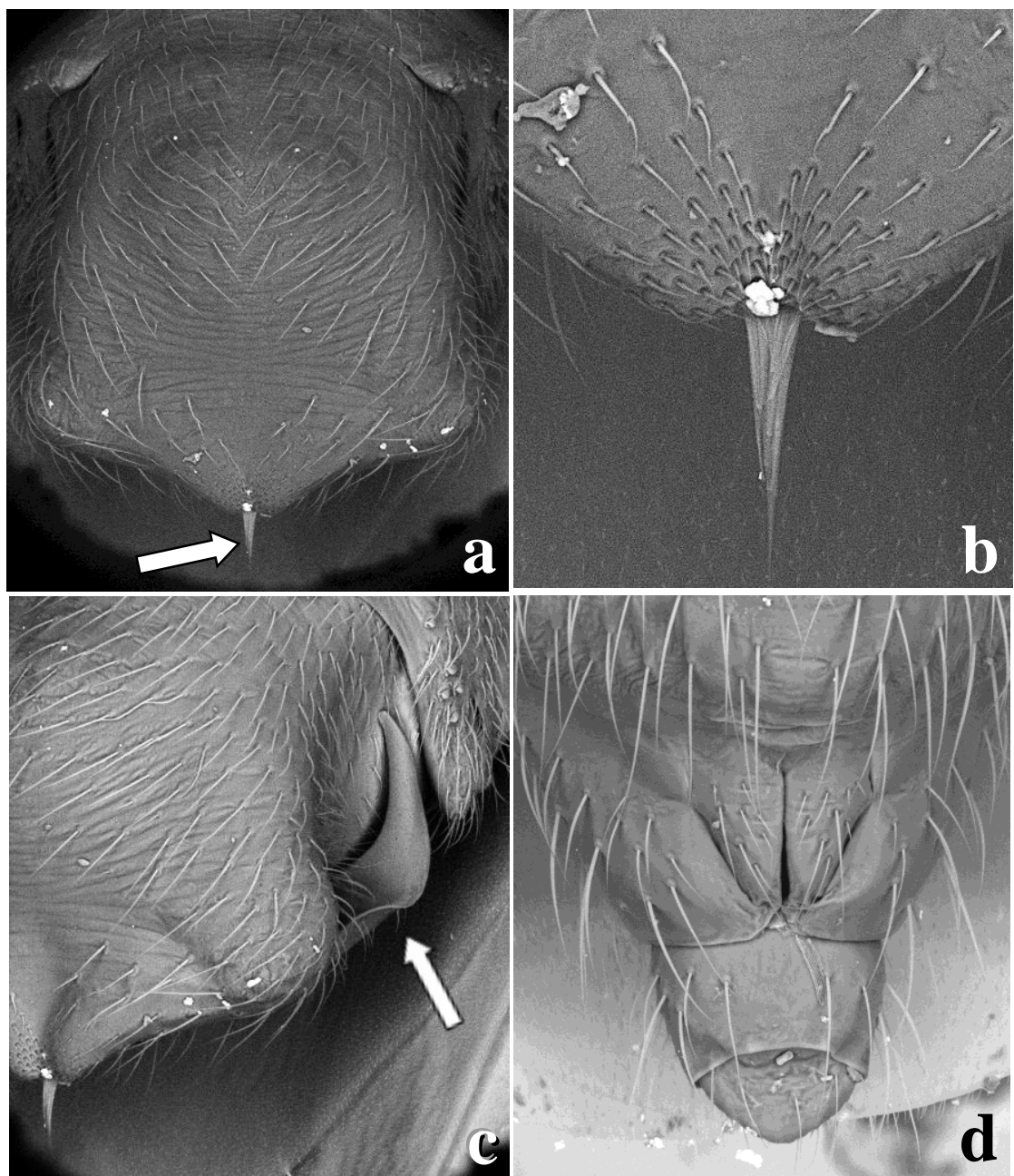

Figure 11. External genitalia of male and female Arachnocoris portoricensis n. sp. paratype. a). Ventral view of male terminal segments. b). Close-up of distalmost portion of panel a (arrowhead). Note tip of aedeagus is vested with long setae. c). Ventrolateral view of abdomen, showing left paramere (arrow). d). Ventral view of female terminal segments. Scale bars: a) $100 \mu \mathrm{m}$, b) $25 \mu \mathrm{m}$, c) $100 \mu \mathrm{m}$, and d) $50 \mu \mathrm{m}$. 

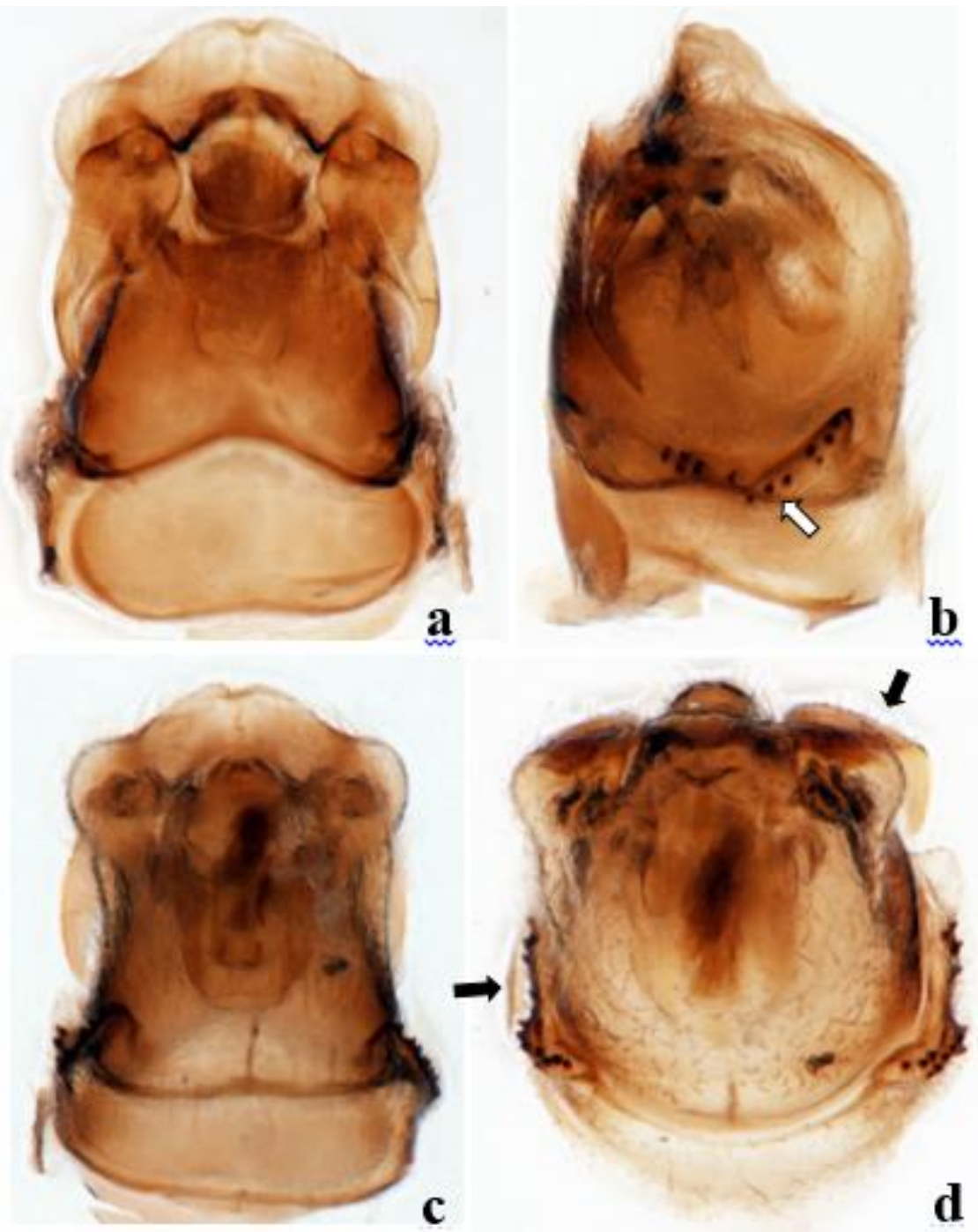

Figure 12. Male paratype genital capsule of Arachnocoris portoricensis n. sp. a). Dorsal. b). Lateral, arrow points to sclerotized denticles. c). Ventral. d). Posterior, top arrow points to setose paramere, bottom arrow to sclerotized denticles.

Morphometrics: Male holotype- Total length $2.8 \mathrm{~mm}$. Head length $0.3 \mathrm{~mm}$, width at eye level $0.4 \mathrm{~mm}$, at vertex $0.2 \mathrm{~mm}$, at base $0.3 \mathrm{~mm}$. Length of rostral segment I - $0.2 \mathrm{~mm}$, II $-0.4 \mathrm{~mm}$, III - $0.3 \mathrm{~mm}$, IV - $0.2 \mathrm{~mm}$. Length of antennomere I - $0.3 \mathrm{~mm}$, II $-0.4 \mathrm{~mm}$, III - $0.8 \mathrm{~mm}$; IV - $0.6 \mathrm{~mm}$. Distance 
between ocelli $0.1 \mathrm{~mm}$, between ocelli and eye $0.04 \mathrm{~mm}$. Pronotum length 0.6 $\mathrm{mm}$ (including collar $0.1 \mathrm{~mm}, 0.2 \mathrm{~mm}$ and posterior lobe $0.3 \mathrm{~mm}$ ); width at collar $0.3 \mathrm{~mm}$, at anterior lobe margin $0.4 \mathrm{~mm}$, at humeri $0.8 \mathrm{~mm}$. Scutellum width $0.3 \mathrm{~mm}$, length $0.2 \mathrm{~mm}$. Profemora length $1.0 \mathrm{~mm}$, protibia $1.0 \mathrm{~mm}$, protarsi $0.4 / 0.4 \mathrm{~mm}$ including claws; mesofemora $1.0 \mathrm{~mm}$, mesotibia $1.0 \mathrm{~mm}$, mesotarsi $0.3 / 0.4 \mathrm{~mm}$ with claws; metafemora $1.1 \mathrm{~mm}$, metatibia $1.5 \mathrm{~mm}$, metatarsi not present in specimen. Female paratype from same locality as holotype - Total length $3.1 \mathrm{~mm}$. Head length $0.3 \mathrm{~mm}$, width at eye level $0.4 \mathrm{~mm}$, at vertex $0.2 \mathrm{~mm}$, at base $0.3 \mathrm{~mm}$. Length of rostral segment I- $0.2 \mathrm{~mm}$, II- 0.4 $\mathrm{mm}$, III- $0.4 \mathrm{~mm}$, IV- $0.3 \mathrm{~mm}$. Length of antennomere I- $0.5 \mathrm{~mm}$, II- $0.7 \mathrm{~mm}$, III- $0.9 \mathrm{~mm}$, IV- $0.6 \mathrm{~mm}$. Distance between ocelli $0.6 \mathrm{~mm}$, between ocelli and eye $0.1 \mathrm{~mm}$. Pronotum length $0.6 \mathrm{~mm}$ (including collar $0.1 \mathrm{~mm}, 0.2 \mathrm{~mm}$ and posterior lobe $0.4 \mathrm{~mm}$ ); width at collar $0.4 \mathrm{~mm}$, at anterior lobe margin $0.4 \mathrm{~mm}$, at humeri $0.8 \mathrm{~mm}$. Scutellum width $0.4 \mathrm{~mm}$, length $0.3 \mathrm{~mm}$. Profemora length $1.1 \mathrm{~mm}$, protibia $1.1 \mathrm{~mm}$, protarsi $0.4 / 0.4 \mathrm{~mm}$ with claws; mesofemora $1.1 \mathrm{~mm}$, mesotibia $1.0 \mathrm{~mm}$, mesotarsi $0.4 / 0.40 \mathrm{~mm}$ with claws; metafemora $1.2 \mathrm{~mm}$, metatibia $1.6 \mathrm{~mm}$, metatarsi $0.4 / 0.5 \mathrm{~mm}$ including claws.

Etymology: The specific epithet, portoricensis, is formed by the type locality, Puerto Rico, and the suffix, meaning geographical provenance.

Remarks: Arachnocoris portoricensis n. sp. was initially recorded as Velidia berytoides by Maldonado-Capriles and Navarro (1967). The species was subsequently placed in the genus Arachnocoris by Kerzhner (2007) who maintained its synonymy with $A$. berytoides from the Lesser Antillean island of Grenada, located some $800 \mathrm{~km}$ southeast of Puerto Rico, and identified material from the NMNH as A. berytoides. We could not satisfactorily identify specimens from Puerto Rico and Hispaniola using Kerzhner's (2007) diagnostic key and the description of $A$. berytoides, which Kerzhner based solely on Grenadian specimens as well as other published descriptions treating the West Indian species (Harris 1928, China 1946, Lopez-Moncet 1990).

Arachnocoris trinitatis Bergroth, 1916

(Figures 3a, 4a, and 13-15)

Arachnocoris trinitatis Bergroth, 1916:232; Costa-Lima 1927:544; Harris 1928:28; China 1946:121; Kerzhner 2007:226; Kuznetsova et al. 2007:17; Sewlal and Starr 2008:132; Sewlal and Starr 2009:59; Volpi and Coscarón 2010:53.

Type Material: Holotype, male, Trinidad (Montserrat, A. Busck). Paratypes, two males and one female (allotype). Same data as holotype, Cat. No. 20151 (NMNH). 
Distribution: Reported from Brazil to Venezuela (South America) and Trinidad (West Indies).

Host: Pholcidae: Coryssocnemis simla Huber, Mesabolivar aurantiacus (MelloLeitão).

Other material examined: Seven males, two females, as follows: Four males from Trinidad, W. I. / Arima-Blanchisseuse / R[oa]d, 10.40' [']N, 60.18'W / 28III-2002, C. K. Starr / \& J. N. Sewlal colls // One nymph/ in alcohol - / see immatures / collection. Two males, one female from Trinidad: Mt. St. Benedict / 16 April 2008, J. N. Sewlal \& / C. K. Starr, in web of / Corryssocnemis simila (Pholcidae) // One female from Trinidad/BWI/31-XII-35//Sta. III / Chapin and / Blackwelder. One male from Venezuela / Monagas/Maturin / Col. Duv?t/13.XI.59. All at NMNH.

Diagnosis. Largest described West Indian species, mostly dark brownish red, femora not banded (Figure 4a), hemelytra with a light transverse band posterior to dorsal constriction (Figures 13-15).

Description (Adapted from Bergroth, 1916 and Kerzhner 2007 and the study of above type material.) Head: medial and subbasal vittae ivory or cream colored, below light brownish-red; rostrum brownish red to black; antenna mostly brownish red to black, apex of antennomeres I-II ivory, antennomere IV (except base and apex) pale yellow to red; antennomere I as long as head, II nearly twice the length of I, III distinctly longer than II, IV somewhat shorter than II. Thorax: pronotal collar and anterior lobe dark reddish brown, smooth and shiny, median impression shallow, posterior lobe shiny, finely and thickly punctate with an extremely short erect ivory pubescence and a few long setae; posterolateral margin ivory, reflexed; scutellum with a whitish, short, and semierect spine at apex; hemelytra extending passed tip of abdomen, with a transverse whitish band just posterior to its narrowest section, apical triangle of corium whitish. Legs: black; extreme apex of all femora, and a rather broad annulation to hind femora yellowish or brownish red; tibiae and tarsi reddish brown, base of tibiae narrowly whitish; middle femora not incrassate in either sex. Abdomen: Male - brassy brown colored; constricted between segments II and III; tergites, except I, II, IX, and middle part of III membranous or only with small sclerotized areas in the middle; a pair of reddish-yellow abdominal scent gland openings; sternum III the longest, sterna II-IV fused, sterna II to VII, mostly in their lateral parts, with large round ivory spots formed by weakly sclerotized areas; ventral segments (except fourth and sixth) at the lateral margins, and second ventral segment at middle of apical margin with an ivory white callus; sternum VIII of male not drawn under the VII, subequal to it in length, with a row of teeth on hind margin; propleura, margin of acetabula and 
(procoxal pan) ivory. Aedeagus: short, with two symmetrical, long, pointed spiculi; seminal duct on apical two-thirds with strongly thickened walls; parameres "sickle shaped" but with a "hook" facing inward towards abdomen, with a single sharp apex and setae present on external basal surfaces; a pair of sclerotized spiculi on inner base of endophallus "endosoma".

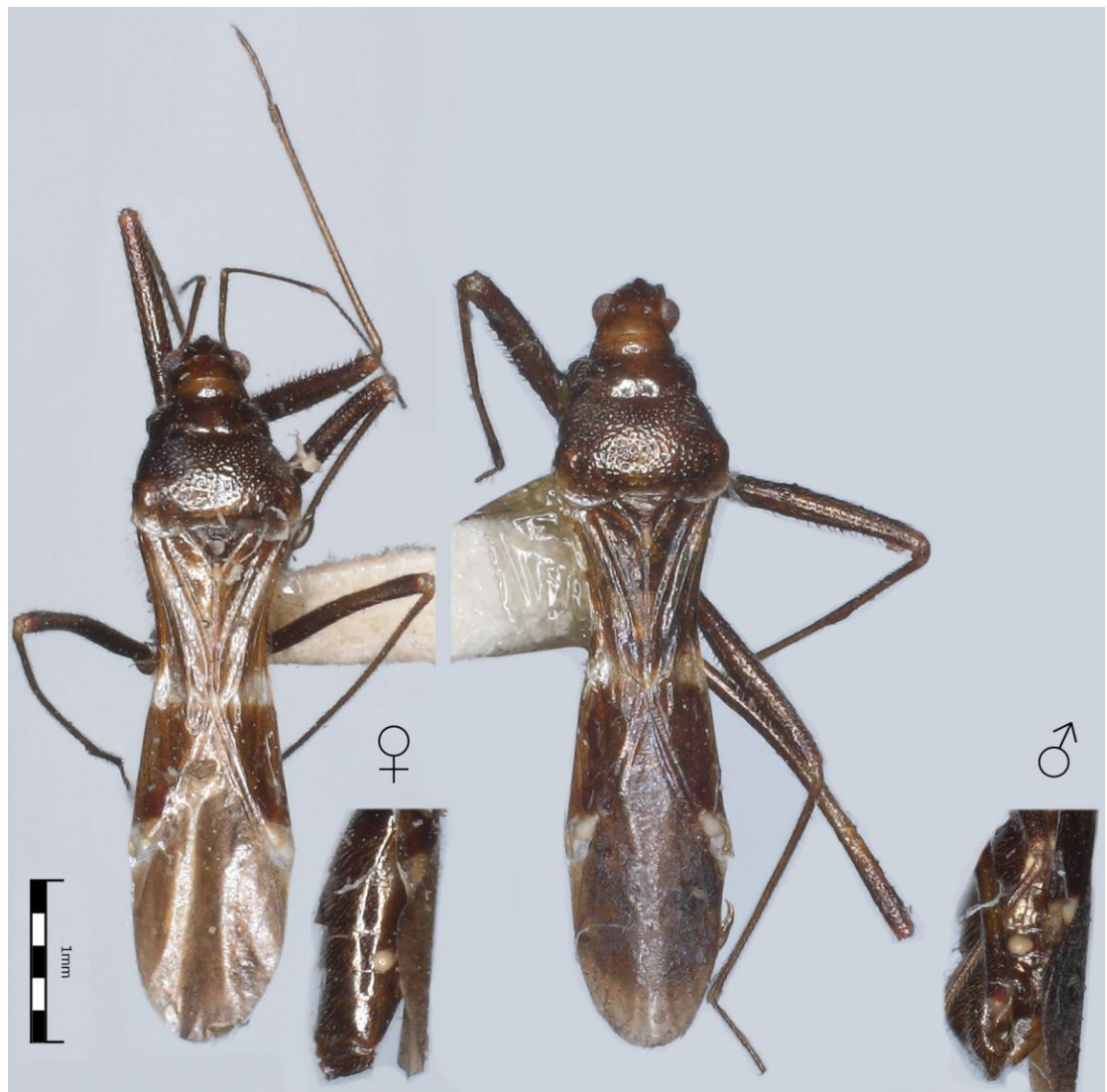

Figure 13. Dorsal habitus and ventral laterotergites of Arachnocoris trinitatis Bergroth female (left) and male (right). Scale bar $=1 \mathrm{~mm}$. 

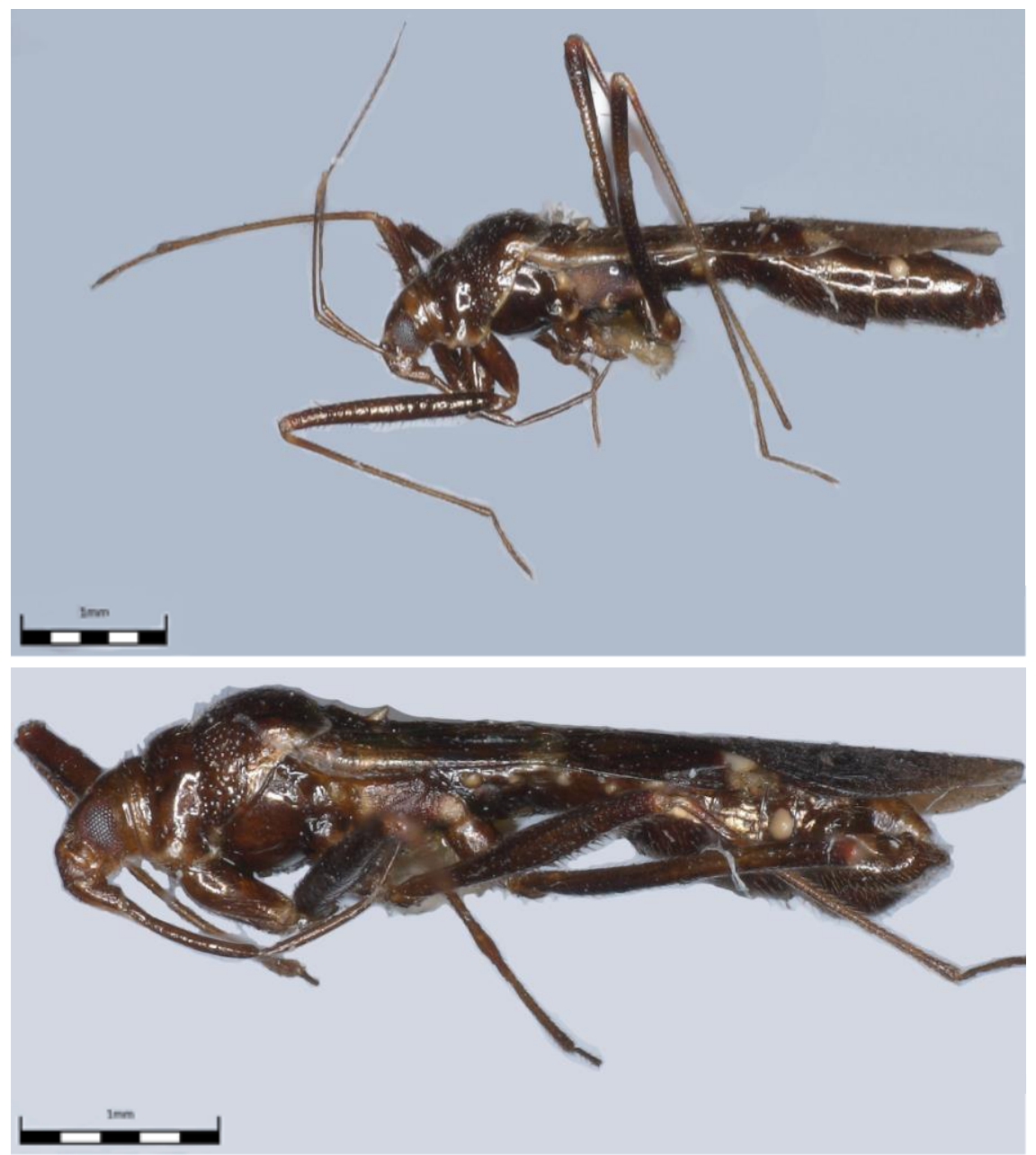

Figure 14. Lateral habitus of Arachnocoris trinitatis Bergroth female (top) and male (bottom). Scale bars $=1 \mathrm{~mm}$. 


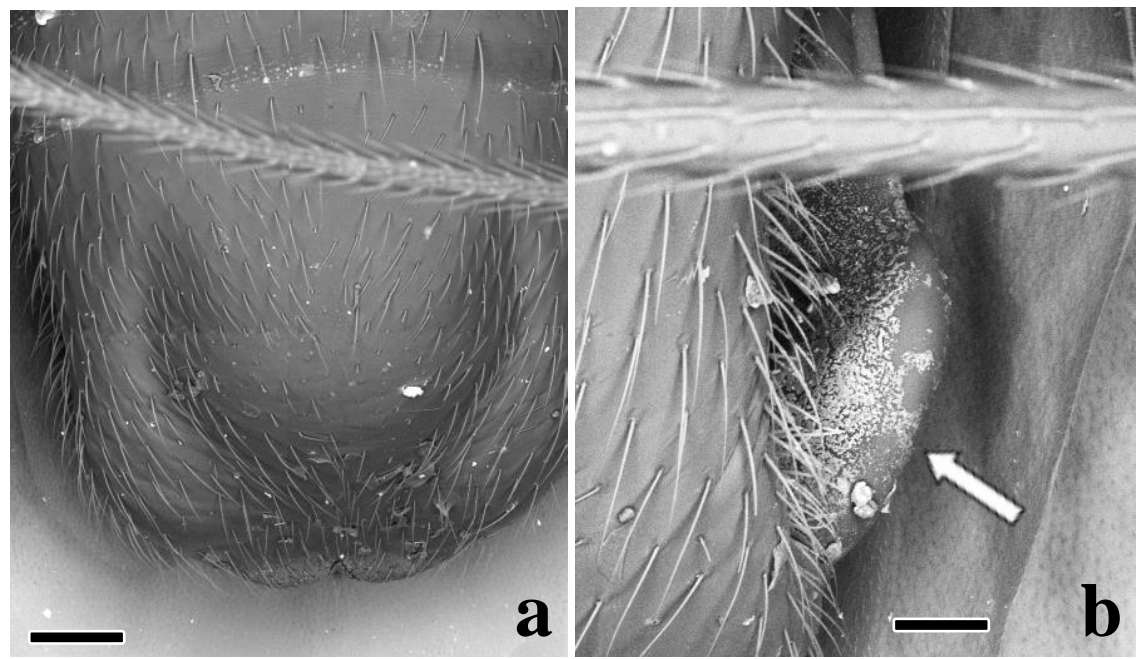

Figure 15. External genitalia of male and female Arachnocoris trinitatis Bergroth. a). Ventral view of male's segment VIII. b). Ventrolateral view of abdomen, showing basal portion of left paramere (arrow). Scale bars: a) $100 \mu \mathrm{m}$, b) $50 \mu \mathrm{m}$.

\section{Discussion}

Due to differences of what we suggest represent biologically important color patterns of the antenna and the femora, as well as the length ratios of the antennomeres of $A$. portoricensis (Puerto Rico), A. darlingtoni (Hispaniola), A. berytoides (Grenada), and A. karukerae (Guadeloupe); we consider each to represent valid species. We also do not agree with the synonymy of $A$. karukerae with A. berytoides, made by Kerzhner (2007), as we understand Kerzhner did not examine specimens of A. karukerae. The late hemipterologist, Dr. Jacques Carayon, studied exemplars of Arachnocoris from Guadeloupe and recommended to Lopez-Moncet to recognize them as a valid species (LopezMoncet, personal communication to author JEM 2009). Although extensive efforts were undertaken to locate specimens of A. karukerae (see Acknowledgments), none were secured. Based on Carayon's comments and our own re-evaluation of the original description, we are reinstating the original designation of Lopez-Moncet until additional specimens are examined.

Except for Arachnocoris trinitatis, West Indian species of Arachnocoris are similar to the continental A. torquatus Bergroth, in having a shorter antennomere I (i.e., that is slightly shorter in length than the length of the head). Arachnocoris trinitatis resembles most other continental species in having an antennomere I slightly longer than the length of the head, a dark overall coloration, and a white transverse band posterior to the hemelytral constriction.

Arachnocoris remains a little-studied group of fascinating arachnophilic hemipterans. We hypothesize that, first, the geographic isolation of this weakly- 
flying group was the major speciation driver of West Indian Arachnocoris, a likely case of allopatric speciation. Based on the known distribution (see Catalog, below), species of Arachnocoris appear to have a small geographical distribution. Later, we suggest, through natural selection, an arms race coevolution developed between Arachnocoris and each of their spider hosts, mainly pholcids in the genus Modisimus Simon, resulting in the incorporation of phenotypic traits that facilitate the perhaps highly specialized kleptoparasitic niche of Arachnocoris. The color patterns of the antennae and femora are diagnostic for the West Indian species and may have evolved to mimic their particular spider hosts (Mercado and Santiago-Blay 2015). Modisimus spiders have considerable island species-level endemism, especially in some of the islands, such as Hispaniola (Huber et al. 2010). Additionally, there is no evidence of host sharing between any two species of Arachnocoris.

The potential reproductive isolation among the species of Arachnocoris due to morphological misfit between male and female genitalia is best determined in mating experiments since: 1) it is often difficult to know the precopulatory isolating mechanisms and 2) successful copulation does not imply the production of progeny. Should an abundance of specimens become available, we encourage colleagues to test our speciation hypothesis for Arachnocoris.

We hope that this paper, as well as Mercado and Santiago-Blay (2015), will raise awareness of the complex ecological interactions that occur on spider webs (e.g., Wheeler 1928). Also, we expect that these papers will encourage additional systematic work in museum collections and field work as almost certainly more species remain to be described.

\section{Catalog of the Species of Arachnocoris}

\section{Arachnocoris alboannulatus Costa-Lima, 1927}

Arachnocoris alboannulatus Costa-Lima, 1927:541; Costa-Lima, 1940:236; China, 1946:121; Henry, 1984:56; Kerzhner, 1986:180; Volpi and Coscarón, 2010:52.

Type Material: Syntypes, 1 male and 1 female - [Brasil, Rio de Janeiro State], Rio [de Janeiro], Jardim Botânico, V.1927, Moraes Mello col. (CEIOC12944; support 6, bottle 58; box 6, divisions 5-7, slides 155-157). CEIOC is the acronym for "Coleção Entomológica do Instituto Oswaldo Cruz, Fundação Oswaldo Cruz, Rio de Janeiro, Brazil.

Distribution: Brazil (South America).

Spider Host: Mesabolivar togatus Keyserling (Pholcidae). Undetermined on original description. Herein determined from examining Dr. B. A. Hubber's online 
photographs of Pholcidae (Huber 2015a) depicting both the spider host and an $A$. alboannulatus http://www.pholcidae.de/alive pholcids/mesabolivar91_l.jpg; last accessed May 29, 2016). An immature of an undetermined species of Arachnocoris is depicted with Mesabolivar sai Huber, 2015b (Huber 2015a, http://www.pholcidae.de/alive_pholcids/mesabolivar6a_l.jpg); last accessed May 29, 2016).

\section{Arachnocoris albomaculatus Scott, 1881}

Arachnocoris albomaculatus Scott, 1881:273; Bergroth 1914:117; Myers 1925:136; Costa-Lima 1927:543; Harris 1928:28; China and Myers 1929:123; China 1946:121; Davis 1961:347; Froeschner 1999:138; Kerzhner 1986:180; Lopez-Moncet 1990:3; Volpi and Coscarón 2010:52. Arachnocoris albomaculata: China 1946:120.

Type Material: BMNH. No. 36/ O.P.C / Perpunha/ Rio Jane ${ }^{\circ}$ [iro, Brazil]. // Type // Sex? // Syntype // BMNH(E)/ 1705832. This specimen has associated dissected structures. Coauthor MDW considers Scott types deposited at the BMNH as syntypes as Scott does not indicate how many specimens he studied as far as we can garner from the original descriptions.

Additional (non-type) specimens at BMNH: Brazil: 1 female / Fordlandia / Rio Tapajos. / 1932. J.G.Myers//. 3 male, 1 female, Barro Colo- / rado. C.Z. [Canal Zone]/ x1 male 13.VII.[19]24, x1 male 24.VII.[19]24, x1 male 1 female 31.VII.[19]24/ N. Banks//

Distribution: Brazil and Panama (as determined by Bergroth 1914; although this might need revision) (South America).

Spider Host: Unspecified communal spider.

\section{Arachnocoris berytoides (Uhler, 1894)}

Velidia berytoides Uhler, 1894:207; Bergroth, 1914: 116; Costa-Lima, 1927:541; Maldonado-Capriles and Navarro, 1967:49; Woodruff et al., 1998:93.

Arachnocoris berytoides Bergroth, 1914:116; Costa-Lima, 1927:541; Harris, 1928:28; Lopez-Moncet, 1984:3; Lopez-Moncet, 1997:531; Kerzhner, 2007:226; Volpi and Coscarón, 2010:52; Coscarón and Volpi 2013:94.

Type Material: Holotype, male, BMNH. One male topotype, one immature topotype, BMNH. 
Distribution: Grenada (West Indies).

Spider Host: Unknown.

4. Arachnocoris darlingtoni Santiago-Blay and Mercado 2016, this publication.

Type Material: Holotype, male; paratype, female, both at AMNH.

Distribution: Dominican Republic (Hispaniola, West Indies).

Spider Host: Unknown

\section{Arachnocoris dispar Scott, 1881}

Arachnocoris dispar Scott, 1881:274; Costa-Lima, 1927:543; China, 1946:121; Volpi and Coscarón, 2010:52.

Type Material: One syntype with the following information: BMNH. No. 72 / O.P.C / Para in/ spiders webs (under specimen card mount reads: No. 72 / Para / O.P.C. / spiders // Type // Syntype // Female // BMNH(E) / 1705833. Co-author MDW considers Scott types deposited at the BMNH as syntypes as Scott does not indicate how many specimens he studied as far as we can gather from the original descriptions.

Additional specimens in BMNH: Five specimens (sex undetermined) Brazil / Amazonas / 1932. J.G.Myers // Cating / Uraricuera, / Savannahs. // [Two specimens have genitalia dissections in vials.]

Distribution: Brazil (South America).

Spider Host: Unspecified communal spider.

\section{Arachnocoris eberhardi Kerzhner, 1990}

Arachnocoris eberhardi Kerzhner, 1990:133; Volpi and Coscarón, 2010:52.

Type Material: Holotype, male, NMNH; paratypes, 3 females and 1 immature, NMNH and 1 female, ZISP.

Distribution: Costa Rica (Central America). 
Spider Host: Unspecified spiders in the family Pholcidae.

7. Arachnocoris karukerae Lopez-Moncet, 1990

Arachnocoris n. sp. Lopez-Moncet, 1984:3.

Arachnocoris karukerae Lopez-Moncet, 1990:3; Lopez-Moncet, 1997:528; Volpi and Coscarón, 2010:52.

A. berytoides: Kerzhner, 2007:229; Coscarón and Volpi, 2013:94.

Type Material: Holotype, female, MBBF; paratypes, five additional females, MBBF, type material is lost.

Distribution: Guadeloupe (unconfirmed from Martinique), West Indies.

Spider Host: A spider in the family Pholcidae. Originally described as a “Modismus sp.?" by Lopez-Moncet (1990). Remarks: It is probable that the true host of this species is Mecolaesthus taino Huber (2000) since no Modisimus species are documented from Guadeloupe and since M. taino shares its collection data, i.e. "La maison de la Forêt", Basse Terre, Guadeloupe, Lesser Antilles; Aug. 1983 (A. Lopez), in AMNH (see Huber 2000).

8. Arachnocoris myersi China, 1946

Arachnocoris myersi China, 1946:119; Volpi and Coscarón, 2010:52.

Type Material: Holotype, male, BMNH. Arachnocoris / myersi China / Type $\widehat{\imath}$ // Det. W.E. China. 1946. // Barreiras de Janaria / R. Solimoes / 9. 1. [18]75 // In stump of / Iriartea ventricosa [Arecaceae, a palm)] // Type // Amazons. / (Trail) / 97-71. // Dissected / J. A. Grant. 1963. // BMNH(E) / 1705834 [This specimen has associated dissected structures.] // Paratype, female, BMNH. Arachnocoris / myersi China / Type 9 // Det. W.E. China. 1946 // Brazil / R. Solimoes / 9. i. 1875 / (Trail Coll.) // Pres. By/ J.Richie/ Curator Perth Mus. / B.M.1929-79. // Paratype // BMNH(E) / 170585

Distribution: Brazil (South America).

Spider Host: Unspecified spider. 
9. Arachnocoris panamensis (Distant, 1893)

Herdonius panamensis Distant, 1893:419; Bergroth, 1914:116; Carvalho and Dolling, 1976:803; Schuh, 1995:668.

Arachnocoris panamensis Bergroth, 1914:116; Bergroth, 1916:232; Myers, 1925:136; Costa-Lima, 1927:543; Harris, 1928:28; Carvalho and Dolling, 1976:803; Froeschner, 1999:138; Kerzhner, 1986:180; Kerzhner, 1990:133; Volpi and Coscarón, 2010:52.

Arachnocoris albomaculatus: Myers, 1925:136; Harris, 1928: 28

Arachnocoris albomaculata: Harris, 1926:2.

Type Material: Holotype, male, BMNH // Bugaba / Panama / Champion // C. A., Hem. I / Herdonius / panamensis // Herdonius? / panamensis / Dist. [handwritten] // $\mathrm{Sp}$ [ecimen]. Figured. // Lectotype // $q$ // $\mathrm{BMNH}(\mathrm{E}) /$ 1705831. Designated by Carvalho and Dolling, 1976, where they say the holotype is a female, not a male, as stated in the original description.

Distribution: Costa Rica and Panamá (Central America).

Spider Host: Theridion fordum Keyserling (Theridiidae), Acrosoma sp. (Araneidae).

10. Arachnocoris portoricensis Mercado, 2016, this publication.

Velidia berytoides: Maldonado-Capriles and Navarro, 1967:49.

Arachnocoris berytoides: Kerzhner, 2007:229; Volpi and Coscarón, 2010: 52; Coscarón and Volpi 2013:52.

Type Material: Holotype, male, NMNH; paratype, female, NMNH.

Distribution: Puerto Rico (West Indies).

Spider Host: Primary host is an undescribed species in the family Pholcidae, found less frequently on the webs of Modisimus signatus (Banks) (Pholcidae). 
11. Arachnocoris setosus Kerzhner, 1990

Arachnocoris setosus Kerzhner, 1990:133; Volpi and Coscarón, 2010:53.

Type Material: Holotype, male, NMNH; paratypes, one male and one female, $\mathrm{NMNH}$.

Distribution: Costa Rica (Central America).

Spider Host: Unspecified spider in the family Pholcidae.

12. Arachnocoris simoni Bergroth, 1899

Arachnocoris simoni Bergroth, 1899:295; Bergroth, 1914:117; Costa-Lima, 1927:544; China, 1946:121; Volpi and Coscarón, 2010:53.

Type material: Type material: Syntype(s): female, collected in Caracas, Venezuela by E. Simon. Depository not specified. Bergroth (1899) gives only one measurement, this may indicate that he had just one specimen.

Distribution: French Guyana and Venezuela (South America).

Spider Host: Unspecified spider.

13. Arachnocoris thesauri Lopez-Moncet, 1997

Arachnocoris thesauri Lopez-Moncet, 1997:530; Coscarón and Volpi, 2013:94.

Type Material: Type material not specified. It is a single female. Collected in mountains near the Roura commune, French Guyana. From the cobwebs of Pholcidae at the buttresses of Carapa guianensis Aubl. (Meliaceae) and Inga sp. (Fabaceae) (July 1995). MBBF (presumed lost).

Distribution: French Guyana (South America).

Spider Host: Possibly Physocyclus globosus Taczanowski (Pholcidae). 
14. Arachnocoris torquatus Bergroth, 1914

Arachnocoris torquatus Bergroth, 1914:117; Costa-Lima, 1927:544; China, 1946:121; Volpi and Coscarón, 2010:53.

Type material: Holotype: male, collected in Caracas, Venezuela by E. Simon. Depository not specified. Bergroth (1899) explains: "The following species is so distinct and easily recognised from the others that I describe it, although the type is not in the best condition". From this, we may safely assume that he had just one specimen.

Distribution: Caracas, Venezuela (South America).

Spider Host: Unspecified spider.

15. Arachnocoris trinitatis Bergroth, 1916

Arachnocoris trinitatis Bergroth, 1916:232; Costa-Lima, 1927:544; Harris, 1928:28; China, 1946:121; Kerzhner, 2007:226; Kuznetsova et al., 2007:17; Sewlal and Starr, 2008:132; Sewlal and Starr, 2009:59; Volpi and Coscarón, 2010:53.

Type Material: Holotype, male, Montserrat [Hills], Trinidad [and Tobago] (Montserrat, A. Busck); allotype, female; paratypes, two males. All under Cat. No. 20151, NMNH.

Distribution: Brazil to Venezuela (South America) and Trinidad (West Indies).

Spider Host: Coryssocnemis simla Huber (Pholcidae), Mesabolivar aurantiacus (Mello-Leitão) (Pholcidae).

16. Arachnocoris varius Lopez-Moncet, 1997

Arachnocoris varius Lopez-Moncet, 1997:530; Coscarón and Volpi, 2013:94.

Type Material: Type material was not specified in the original description. It is composed of four males and eight females. Collected in mountains near the Roura commune, French Guyana. From the cobwebs of Pholcidae at the base of Carapa guianensis (Meliaceae) and Inga sp. (Fabaceae) (July 1995). MBBF (presumed lost). 
Distribution: French Guyana (South America).

Spider Host: Possibly Physocyclus globosus Taczanowski (Pholcidae).

Acknowledgments

Mr. Alfredo D. Colón-Archilla, guided the first author during trips in Puerto Rico. Dr. Thomas J. Henry (Systematic Entomology Laboratory, United States Department of Agriculture at the $\mathrm{NMNH}$ ) and Dr. Randall T. Schuh (AMNH) allowed access to collections and provided extremely useful suggestions. Additionally, both allowed additional imaging and, in the case of $A$. portoricensis, scanning electron micrographs. Dr. Jen Etienne and Dr. Anne-Marie Toussaint [both at the Institut National de Recherche Agronomique (National Institute for Agricultural Research) INRA Antilles-Guyane, Petit-Bourg, Guadeloupe], as well as Dr. Gerard Duvallet (University of Montpellier, Montpellier, France), Dr Lopez-Moncet (Beziers, France), Dr. Pierre Jolivet (Paris, France), Dr. Fedor V. Konstantinov (Department of Entomology, Faculty of Biology, St. Petersburg State University, St. Petersburg, Russia) and Dr. Gunvi Lindberg (Naturhistoriska riksmuseet, Stockholm, Sweden) assisted in the search for specimens of $A$. karukerae and/or three other species whose depository we had not yet found at the time this paper went to press. Curatorial staff at the Museum of Comparative Zoology (Harvard University) searched for specimens of Arachnocoris. Dr. María del Carmen Coscarón helped in finding references. Ms. Nadia Pazolis-Gabriel (Language Services, NMNH) translated Lopez-Moncet (1990) paper. The Rocky Mountain Research Station, the National Museum of Natural History, and the American Museum of Natural History provided the microphotography facilities. Mr. Derek Kohler (Lake Erie College of Osteopathic Medicine, Erie, Pennsylvania, USA) aided JASB in using the linear measurement function within the Scandium (Olympus, Lakewood, Colorado, USA) at the Imaging-Scanning Electron Microscopy Laboratory of the NMNH. Mr. Scott D. Whittaker (Imaging-Scanning Electron Microscopy Laboratory) and Mr. Efraín Tejada (Office of Education and Outreach, NMNH) facilitated the use of the Olympus DSX100 for coauthor Santiago-Bay. Dr. Stephen Thurston (Division of Invertebrate Zoology, AMNH) kindly trained the second author (JASB) on the use of the imaging equipment. Mr. Timothy Rose (Department of Mineral Sciences, NMNH) assisted with the low vacuum scanning electron microscopy of the metal uncoated exemplars of Arachnocoris. Dr. Jane Costa (Curator, Entomological Collection of the Oswaldo Cruz Institute), Dr. Felipe Ferraz Figueiredo Moreira (Technologist, Entomological Collection of the Oswaldo Cruz Institute), and Thaynara de Souza Martins (undergraduate student of the Entomological Collection of the Oswaldo Cruz Institute) found and imaged the type material of Arachnocoris alboannulatus Costa-Lima. Dr. Luiz Antonio Alves Costa (Departamento de Entomologia, Museu Nacional, Universidade Federal do Rio de Janeiro, Quinta da Boa Vista, São Cristóvão, Rio de Janeiro, Brasil) also looked for the type material of A. alboannulatus. Mr. Richard Wahl (formerly at TheITSupportCenter, LLC, West Conshohocken, Pennsylvania, USA) helped JASB post-process calibrated images. Ms. Yamile Toussaint (TheITSupportCenter, LLC) improved several images. Dr. Eduardo I. Faúndez (North Dakota State University, Fargo, North Dakota, USA) provided a copy of Faúndez and Carvajal (2014). Dr. Peter Belton (Simon Fraser University, Burnaby British Columbia, Canada), Dr. José L Fernández-Triana (Canadian National Collection of Insects, Ottawa, Canada), Dr. Dmitry Musolin (Saint Petersburg State Forest Technical University, Saint Petersburg, Russia) and Dr. John Oswald (Texas A\&M University College Station, Texas, USA), provided references and/or engaged in interesting discussions on wing size variability in insects. This manuscript was benefited by the invaluable comments of Dr. Boris C. Kondratieff and Dr. Paul Ode (both at C. P. Gillette Museum of Arthropod Diversity, Colorado State University's Fort Collins Colorado, USA). Dr. Christiane Weirauch (University of California, Riverside, California, USA) provided important information about morphological structures. Dr. Valérie Lemaître (The Natural History Museum, England, United Kingdom) provided numerous stable links to older references and a last, extremely valuable, reading of the manuscript. Three additional reviewers also made helpful suggestions for which we are grateful. 


\section{Literature Cited}

Andersen, N. M. 1982. The Semiaquatic Bugs (Hemiptera, Gerromorpha): Phylogeny, Adaptations, Biogeography, and Classification. Entomonograph (Volume 13). Klampenborg, Denmark. Scandinavian Science Press. Klampenborg, Denmark. 455 pp.

Bergroth, E. 1899. Diagnose d'une nouvelle espèce du genre Arachnocoris Scott (Nabidae) (Hem.). Bulletin de la Société entomologique de France 15:295-296. http://biodiversitylibrary.org/page/8260717

Bergroth, E. 1914. Note on the genus Arachnocoris Scott. The Entomologist's Monthly Magazine, 2nd Series 25(293):116-117. http://biodiversitylibrary.org/page/9264218

Bergroth, E. 1916. New and little known heteropterous Hemiptera in the United States National Museum. Proceedings of the United States National Museum 51:215-239. http://dx.doi.org/10.5479/si.00963801.2150.215

Borror, D. J., C. A. Triplehorn, and N. F. Johnson. 1989. An Introduction to the Study of Insects (Sixth Edition). Saunders College Publishing. Philadelphia, USA. 875 pp.

Carvalho, J. C. M. and W. R. Dolling. 1976. Neotropical Miridae, CCV: type designations of species described in the "Biologia Centrali Americana" (Hemiptera). Revista Brasileira de Biologia 36:789-810. http://research.amnh.org/pbi/library/0226.pdf

China, W. E. and J. G. Myers. 1929. XIII. - A reconsideration of the classification of the cimicoid families (Heteroptera), with the description of two new spider-web bugs. The Annals \& Magazine of Natural History Series 3, 3:97-125. http://dx.doi.org/10.1080/00222932908672943

China, W. E. 1946. XV-A new species of the genus Arachnocoris Scott with a key to the known species of the genus (Hemiptera, Nabidae). The Annals \& Magazine of Natural History 13(98):119-122. http://dx.doi.org/10.1080/00222934608654532

Coscarón, M. del C. and L. N. Volpi 2013. Nomenclatural and bibliographic corrections to the Catalog of Nabidae (Hemiptera: Heteroptera) for the Neotropical Region. Zootaxa 3646(1): 093-096. http://dx.doi.org/10.11646/zootaxa.3646.1.9

Costa A. 1853. Cimicum regni Neapolitani centuria. Atti del Reale Istituto d'Incorragiamento alle Scienze Naturali di Napoli 8: 225-299. http://biodiversitylibrary.org/page/9232845

Costa-Lima, A. da. 1927. Nota sobre as especies do genero "Arachnocoris" (Hemiptera, Nabidae). Sciencia Medica 5:541-544.

Costa-Lima, A. da .1940. Insetos do Brasil. $2^{\circ}$ tomo. Capítulo XXII Hemípteros. Escola Nacional de Agronomia, série didática $\mathrm{N}^{\circ} 3.351 \mathrm{pp}$.

Davis, N. T. 1961. Morphology and phylogeny of the Reduvioidea (Hemiptera: Heteroptera). Part II. Wing venation. Annals of the Entomological Society of America 54:340-354. http://dx.doi.org/10.1093/aesa/54.3.340

Distant, W. L. 1893. Supplement, Appendix + XXXIX plates (Hemiptera -Heteroptera), pp. 304 462. In, Godman, F. D. and O. Salvin (Editors). Biologia Centrali-Americana. R. H. Porter, London, England, United Kingdom. Volume 1, XX + 462 pp. http://biodiversitylibrary.org/page/594498

Dolsan de Almeida, M., J. Mourão dos Santos Rodrigues, F. F. F. Moreira, and J. Jurberg. 2014. Lista dos exemplares-tipo de Heteroptera (Insecta: Hemiptera) da Coleção Costa Lima, Instituto Oswaldo Cruz, Rio de Janeiro, Brasil. EntomoBrasilis 7(2):151-158. http://dx.doi.org/10.12741/ebrasilis.v7i2.411

Faúndez, E. I. 2015. A case of biting humans by Nabis americoferus (Heteroptera: Nabidae), with comments on bites by other species of the genus Nabis in the United States. Journal of Medical Entomology 53(1):230-232. DOI: http://dx.doi.org/10.1093/jme/tjv155

Faúndez, E. I. and M. A. Carvajal. 2014. Contribución al conocimiento del complejo de Nabis punctipennis Blanchard, 1852 (Hemiptera: Heteroptera: Nabidae) en Chile. Anales del Instituto de la Patagonia 42(1):63-69.

Fernández-Triana, J. L. and C. Boudreault. 2016. Keylimepie peckorum gen. n. and sp. n., (Hymenoptera, Braconidae) from southern Florida, U.S., the first known brachypterous member of the subfamily Microgastrinae. ZooKeys 584:95-107. http://dx.doi.org/10.3897/zookeys.584.8319 
Froeschner, R. C. 1999. True bugs (Heteroptera) of Panamá: a synoptic catalog catalog as a contribution to the study of Panamanian biodiversity. Memoirs of the American Entomological Institute (Gainesville, Florida, USA) 61:1-393.

Galbreath J. E. 1975. Thoracic polymorphism in Mesovelia mulsanti (Hemiptera: Mesoveliidae). The University of Kansas Science Bulletin 50(10):457-482.

Galolo, A. R. V., M. A. J. Torres, and C. G. Demayo. 2011. Paramere morphology of two colorrmorphs of the Brown Planthopper Nilaparvata lugens (Stål) (Homoptera: Delphacidae). pp. V2-370-V2-374. In, 2011 2nd International Conference on Environmental Science and Technology. International Proceedings of Chemical, Biological and Environmental Engineering (IPCBEE). IACSIT Press, Singapore. http://ag.udel.edu/delpha/6933.pdf

Gorth, G. and D. Headrick. 2001. A Dictionary of Entomology. Wallingford, Oxon, England, UK. $1032 \mathrm{pp}$.

Harada, T. 1993. Reproduction by overwintering adults of water strider, Aquarius paludum (Fabricius). Zoological Science 10(2):313-319.

Harada, T. 1998. Life history traits of long- and short-winged adults in a water strider, Aquarius paludum amamiensis (Miyamoto). Entomological Science 1:179-184.

Harris, H. M. 1926. Distributional notes on some Neotropical bugs of the family Nabidae, with description of a new species. Proceedings of the United States National Museum 69(21):1-4. http://dx.doi.org/10.5479/si.00963801.2647

Harris, H. M. 1928. A monographic study of the hemipterous family Nabidae as it occurs in North America. Entomologica Americana 9(1-2):1-97. http://biodiversitylibrary.org/page/50727876

Henry, T. J. 1984. Revision of the spider-commensal plant bug genus Ranzovius Distant (Heteroptera: Miridae). Proceedings of the Entomological Society of Washington 86(1):53-67. http://biodiversitylibrary.org/page/16360506

Henry, T. J. 1999. The spider-commensal plant bug Ranzovius (Heteroptera: Miridae: Phylinae) revisited: three new species and a revised key, with the description of a new sister genus and phylogenetic analysis. Acta Societatis Zoologicae Bohemicae 63:93-115.

Henry T. J. 2009. Biodiversity of Heteroptera, pp. 223-263. In, Foottit R. G. and P. H. Adler (Editors). Insect Biodiversity: Science and Society. Wiley-Blackwell. Chichester, England, United Kingdom. 632 pp.

Honěk, A. 1979. Independent response of 2 characters to selection for insensitivity to photoperiod in Pyrrhocoris apterus. Experientia 35(6):762-763. http://dx.doi.org/10.1007/BF01968231

Honěk, A. 1995. Factors and consequences of a non-functional alary polymorphism in Pyrrhocoris apterus (Heteroptera: Pyrrhocoridae). Researches on Population Ecology (Kyoto) 37(1):111118. http://dx.doi.org/10.1007/BF02515768

Huber, B. A. 2000. New World pholcid spiders (Araneae: Pholcidae): a revision at the generic level. Bulletin of the American Museum of Natural History. Number 254. 348 pp. http://digitallibrary.amnh.org/bitstream/handle/2246/1601/B254.pdf;jsessionid=FA036459ED1 8C9F2619F1CAD4235CFEC? sequence $=2$

Huber, B. A. 2015a. Pholcidae. The longest legs in the web. http://www.pholcidae.de/ For images, click on "Photos of alive pholcids ( $>3200)$ ".

Huber, B. A. 2015b. Small scale endemism in Brazil's Atlantic Forest: 14 new species of Mesabolivar (Araneae, Pholcidae), each known from a single locality. Zootaxa 3942(1):1-60. doi:10.11646/zootaxa.3942.1.1 http://dx.doi.org/10.11646/zootaxa.3942.1.1

Huber, B. A., N. Fischer, and J. J. Astrin. 2010. High level of endemism in Haiti's last remaining forests: a revision of Modisimus (Araneae: Pholcidae) on Hispaniola, using morphology and molecules. Zoological Journal of the Linnean Society 158(2):244-299. http://dx.doi.org/10.1111/j.1096-3642.2009.00559.x

Kerzhner, I. M. 1986. Neotropical Nabidae (Heteroptera), 1: A new genus, some new species, and notes on synonymy. Journal of the New York Entomological Society 94(2):180-193. http://biodiversitylibrary.org/page/50772211

Kerzhner, I. M. 1990. Neotropical Nabidae (Heteroptera), 3: Species of the genus Arachnocoris from Costa Rica. Journal of New York Entomological Society 98(2):133-138. 
Kerzhner, I. M. 2007. Nabidae of the West Indies (Heteroptera). Zoosystematica Rossica 16:225234. https://www.zin.ru/journals/zsr/content/2007/zr_2007_16_2_Kerzhner_1.pdf

Kim, K. C. and B. A. McPheron. 1993. Evolution of Insect Pests: Patterns of Variation. John Wiley \& Sons, Inc. New York, NY, USA. 479 pp. Link to most of the book, https://books.google.com/books?id=dDzqU4zO3vgC\&pg=PA185\&lpg=PA185\&dq=macropter ous+insects+that+cannot+fly\&source $=$ bl\&ots $=1 \mathrm{pZtMuGdqD \& sig=FQy7FmSNnpbjZ6nWjfScn}$ xPfU6Q\&hl=en\&sa=X\&ved=0ahUKEwit_IXWu_3MAhXICD4KHVDhAr8Q6AEIHTAA\#v= onepage \&q=macropterous $\% 20$ insects $\% 20$ that $\% 20$ cannot $\% 20 \mathrm{fly} \& \mathrm{f}=$ false

Kuznetsova, V. G., S. Grozeva, J. N. Sewlal, and S. Nokkala. 2007. Cytogenetic characterization of the Trinidad endemic, Arachnocoris trinitatus Bergroth: the first data for the tribe Arachnocorini (Heteroptera: Cimicomorpha: Nabidae). Folia Biologica (Kraków) 55:17-26. http://dx.doi.org/10.3409/173491607780006344

Lopez, A. and B. Lopez. No date. Entoflorachne. http://www.entoflorachne.com/araignee/andre lopez.html and http://www.entoflorachne.com/ (Accessed on May 25, 2016.)

Lopez-Moncet, A. 1984. News on insects considered spider commensals and their hosts. British Arachnologists Society, The Newsletter 40:3-4. http://milichiidae.info/sites/milichiidae.info/files/Lopez\%20A 1984.pdf

Lopez-Moncet, A. 1990. Arachnocoris karukerae n. sp. (Hemiptères: Hétéroptères), nabide commensal de Pholcidae (Araignées) aux Antilles Françaises. Bulletin de la Société des Sciences naturalles 65:3-7.

Lopez-Moncet, A. 1997. Observations systématiques et biologiques sur le genre Arachnocoris Scott 1881 (Hétéroptères: Nabidae) Deuxième note. Lambillionea XCVII(4):528-538. http://www.abebooks.com/Observations-syst\%C3\%A9matiques-biologiques-genreArachnocoris-Scott/10767571311/bd\#\&gid=1\&pid=1

Maldonado-Capriles, J. M. and C. A. Navarro. 1967. Additions and corrections to Wolcott's "Insects of Puerto Rico". Caribbean Journal of Science 7(1-2):45-64.

Mercado, J. E. and J. A. Santiago-Blay. 2015. Multiple model mimicry and feeding behavior of the spider web-inhabiting damsel bug, Arachnocoris berytoides Uhler (Hemiptera: Nabidae), from Puerto Rico. Life: The Excitement of Biology 3(1):20-32. http://dx.doi.org/10.9784/LEB3(1)Mercado.01

Musolin, D. L. and A. Kh. Saulich. 1996. Photoperiodic control of seasonal development in bugs (Heteroptera). Entomological Review 76(7):849-864.

Myers, J. G. 1925. Biological notes on Arachnocoris albomaculatus Scott (Hemiptera; Nabidae). Journal of New York Entomological Society 33:136-146. http://biodiversitylibrary.org/page/50783289

Reuter, O.-M. 1890. Ad Cognitionem Nabidarum. Revue d'Entomologie (Publiée par la Société Française d'Entomologie) 9:289-309. http://biodiversitylibrary.org/page/25453223

Reuter, O.-M. 1908. Bemerkungen über Nabiden nebst Beschreibung neuer Arten. Mémoires de la Société Entomologique de Belgique XV:87-130. http://biodiversitylibrary.org/page/11121875

Sakashita, T., F. Nakasuji, and K. Fujisaki. 1998. Seasonal variation in wing polymorphism of the pyrrhocorid bug, Pyrrhocoris sibiricus (Heteroptera: Pyrrhocoridae). Applied Entomology \& Zoology 33(2):243-246.

Saulich, A. H. and D. L. Musolin. 2007. Seasonal Development of Aquatic and Semiaquatic True Bugs (Heteroptera). St. Petersburg University Press. St. Petersburg, Russia. 205 pp.

Savage, A. A. and K. Feakes. 1991. Morphological variation with interspecific implications in a population of Sigara dorsalis (Leach) (Hemiptera: Heteroptera: Corixidae), and a request for British specimens. Freshwater Forum 1(1):73-77. https://www.fba.org.uk/journals/index.php/FF/article/viewFile/306/210

Schuh, R. T. 1995. Plant bugs of the World (Insecta, Heteroptera, Miridae): Systematic Catalog, Distributions, Host List, and Bibliography. New York Entomological Society. New York, NY, United States. $1329 \mathrm{pp}$.

Schuh R. T. and J. A. Slater. 1995. True Bugs of the World (Hemiptera: Heteroptera): Classification and Natural History. Cornell University Press. Ithaca, New York, USA. 338 pp. 
Schuh, R. T. and S. Štys 1991. Phylogenetic analysis of cimicomorphan family relationships (Heteroptera). Journal of the New York Entomological Society 99(3):298-350.

Scott, J. 1881. Description of a new genus and two species of Hemiptera-Heteroptera from South America. The Entomologist's Monthly Magazine 17:272-274. http://biodiversitylibrary.org/page/9277570

Sewlal, J. N. and C. K. Starr. 2008. Observations of the insect Arachnocoris trinitatus (Heteroptera: Nabidae) as an inquiline in the webs of the spider Mesabolivar aurantiacus (Araneae: Pholcidae). Caribbean Journal of Science 44(1):132-135. http://dx.doi.org/10.18475/cjos.v44i1.a16

Sewlal, J. N. and C. K. Starr. 2009. Observations of the insect Arachnocoris trinitatus (Heteroptera: Nabidae) as an inquiline of the spider Coryssocnemis simla (Araneae: Pholcidae) in West Indies. Zoosystematica Rossica 18(1): 59-61. http://dx.doi.org/10.18475/cjos.v44i1.a16

Simpson, S. J., G. A. Sword, and N. Lo. 2011. Polyphenism in Insects. Current Biology 21(18):R738-R749. http://dx.doi.org/10.1016/j.cub.2011.06.006

Slater, J. A. 1975. On the biology and zoogeography of Australian Lygaeidae (Hemiptera: Heteroptera) with special reference to the Southwest fauna. Journal of the Australian Entomological Society 14:47-64. http://dx.doi.org/10.1111/j.1440-6055.1975.tb02002.x

Socha, R. 2001. Latitudinal gradient in response of wing polymorphism to photoperiod in a flightless bug, Pyrrhocoris apterus (Heteroptera: Pyrrhocoridae). European Journal of Entomology 98(2):167-169. http://dx.doi.org/10.14411/eje.2001.030

Socha R. and J. Šula. 2006. Flight muscles polymorphism in a flightless bug, Pyrrhocoris apterus (L.): Developmental pattern, biochemical profile and endocrine control. Journal of Insect Physiology 52(3):231-239. http://dx.doi.org/10.1016/j.jinsphys.2005.10.009

Solbreck, C. 1986. Wing and flight muscle polymorphism in a lygaeid bug Horvathiolus gibbicollis. Determinants and life history consequences. Ecological Entomology 11(4):435-444. http://dx.doi.org/10.1111/j.1365-2311.1986.tb00322.x

Uhler, P. R. 1894. On the Hemiptera-Heteroptera of the Island of Grenada. Proceedings of the Zoological Society of London 1894:167-224. http://biodiversitylibrary.org/page/35990449

Volpi, L. N. and M. Coscarón. 2010. Catalog of Nabidae (Hemiptera: Heteroptera) for the Neotropical Region. Zootaxa 2513:50-68.

Wheeler, W. M. 1928. The Social Insects. Their Origin and Evolution. Kegan Paul, Trench, Trubner \& Co., Ltd. New York, NY, USA. 378 pp. A 2016 reprint of this classic is partially available online,

https://books.google.com/books?hl=en \&lr=\&id=3zhACwAAQBAJ\&oi=fnd \&pg=PP1\&dq=ara chnocoris+albomaculatus+wheeler+2015\&ots=81Hpdtj7Jc\&sig=Od0o-6DjpsFrUFd5Iwn0oq5hAY\# $\mathrm{v}=$ onepage $\& \mathrm{q}=$ albomaculatus $\& \mathrm{f}=\mathrm{false}$

Woodruff, R. E., B. M. Beck, P. E. Skelley, C. Y. L. Shotman, and M. C. Thomas. 1998. Checklist \& Bibliography of the insects of Grenada \& the Grenadines. Memoirs Series Number 2. Center for Systematic Entomology. Gainesville, Florida, United States. 286 pp.

Wygodzinsky, P. 1952. Los insectos de la Islas Juan Fernández. 2. Reduviidae y Cimicidae. Revista Chilena de Entomología 2:15-19. http://www.insectachile.cl/rchen/pdfs/1952v02/Wygodzinski_1952a.pdf

Zhang, J. E., R. L. Gordon, M. Forthman, W. S. Hwang, K. Walden, D. R. Swanson, K. P. Johnson, R. Meier, and C. Weirauch. 2016. Evolution of the assassin's arms: insights from a phylogeny of combined transcriptomic and ribosomal DNA data (Heteroptera: Reduvioidea). Scientific Reports 6(22177). http://dx.doi.org/10.1038/srep22177 